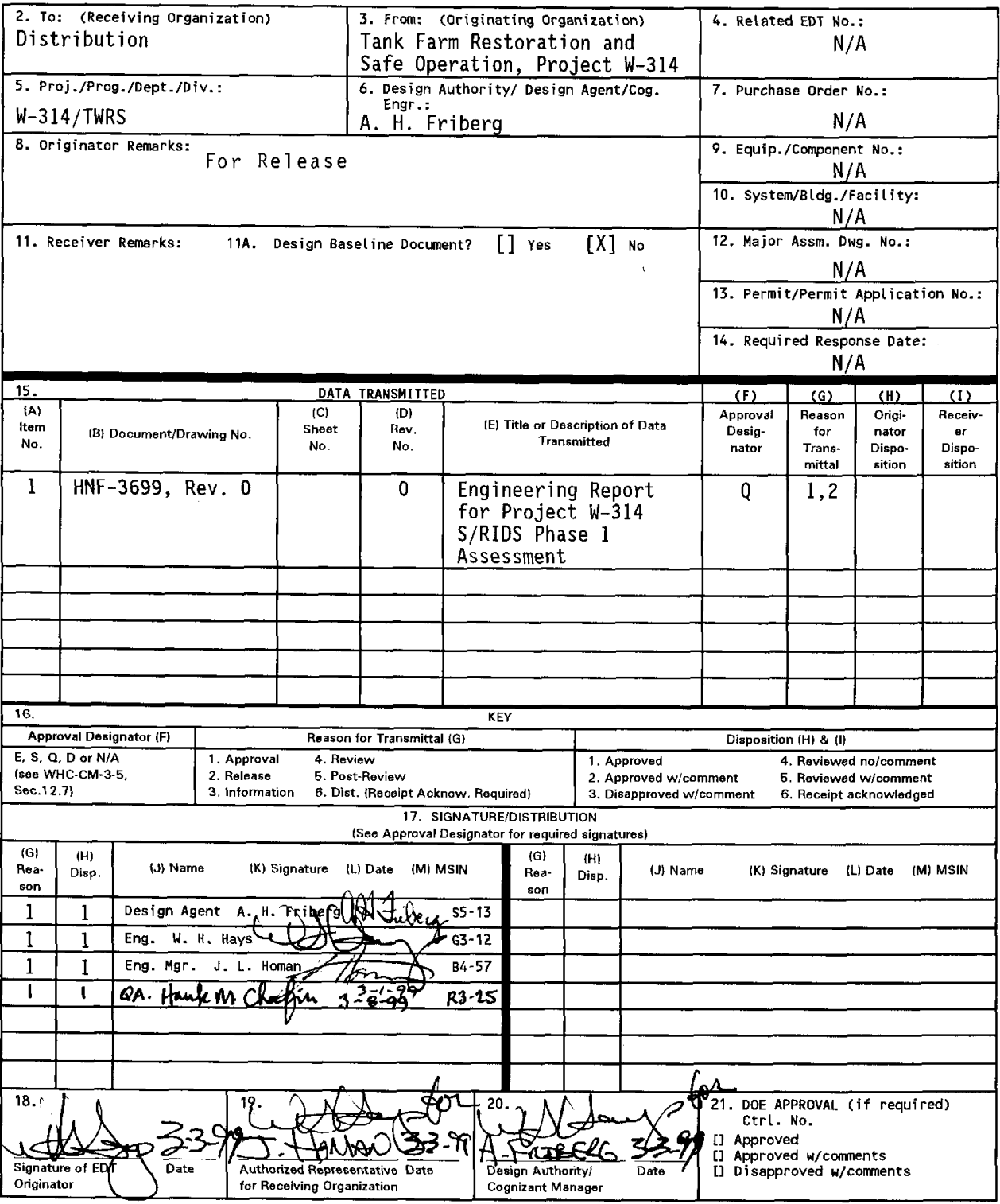




\title{
Engineering Report for Project W-314 S/RID Phase 1 Assessment
}

\author{
A. H. Friberg \\ Fluor Daniel Northwest, Richland, WA 99352 \\ U.S. Department of Energy Contract DE-AC06-96RL13200 \\ EDT/ECN: 618715 \\ UC: 630 \\ Org Code: 8C610 \\ Charge Code: 106048/ED00 \\ B\&R Code: EW3130010 \\ Total Pages: 49
}

Key Words: Project W-314, S/RID, Assessment, TWRS

Abstract:

TRADEMARK DISCLAIMER. Reference herein to any specific commercial product, process, or service by trade name, trademark, manufacturer, or otherwise, does not necessarily constitute or imply its endorsement, recommendation, or favoring by the United States Government or any agency thereof or its contractors or subcontractors.

Printed in the United States of America. To obtain copies of this document, contact: Document Control Services. P.0. Box 950. Mailstop H6-08. Richland WA 99352. Phone (509) 372-2420: Fax (509) 376-4989.
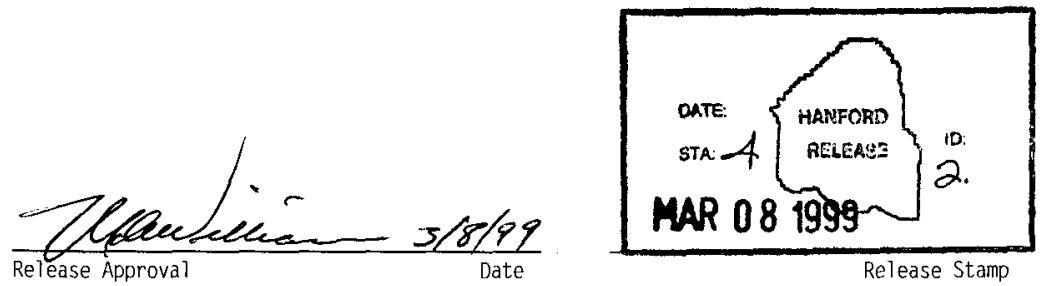

\section{Approved for Public Release}




\section{Engineering Report}

\section{Project W-314 \\ S/RID Phase 1 Assessment}

Prepared for the U.S. Department of Energy

Assistant Secretary for Environmental Management

Project Hanford Management Contractor for the

U.S. Department of Energy under Contract DE-AC06-96RL13200

Approved for public release; distribution is unlimited 
HNF-3699, Rev. 0

\section{TABLE OF CONTENTS}

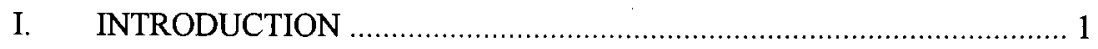

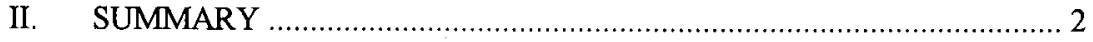

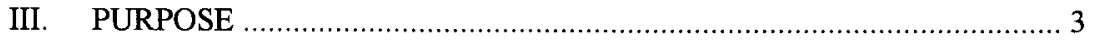

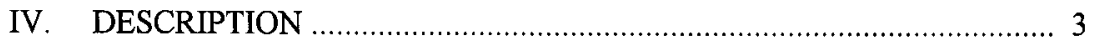

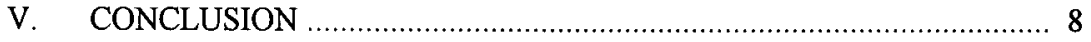

Appendix A Phase 1 Results 


\title{
ENGINEERING REPORT
}

\author{
PROJECT W-314 \\ SIRID PHASE 1 ASSESSMENT
}

\section{INTRODUCTION}

Project W-314, "Tank Farm Restoration and Safe Operation," is in the definitive design stage. A series of readiness reviews will be performed prior to operation, culminating with an Operational Readiness Review (ORR) by the U. S. Department of Energy, Richland Operations Office (RL). Successful completion of the ORR will be used to obtain RL approval to begin operation. This report provides the results of an assessment of project W-314 to assure the definitive design process meets S/RID requirements and to prepare for future readiness reviews.

One of the elements used to determine readiness to operate will be the project's compliance with requirements promulgated through Standards/Requirements Identification Documents (S/RID). An S/RID is a compilation of safety and health requirements for nuclear facilities that are the minimum set needed for safe operation. There are no S/RID requirements developed specifically for project W-314. The applicable S/RIDs are those for the overall Tank Waste Remediation System (TWRS) program of which project W-314 is a part.

The report provides the methodology for determining which of the TWRS S/RIDs apply to project W-314. The methodology was applied to the TWRS S/RIDs, resulting in a set of S/RIDs that apply specifically to project W-314. The documents used by and produced for the project were then compared with the project W-314 S/RIDs and an assessment made of how well the project implemented the S/RIDs. A full S/RID assessment contains two phases: Phase 1 (administrative) determines if documents used by the project implement the S/RIDs; Phase 2 (Adherence) 
HNF-3699 Rev. 0

determines if the project is actually complying with the S/RIDs. This report provides the results of a Phase 1 assessment.

\section{SUMMARY}

This report provides the results of an assessment of project W-314 compliance with project-specific S/RIDs. This Phase 1 assessment has been subdivided into the following tasks.

Task 1 collected reference materials needed to complete the S/RID assessment. The documents include reports from the TWRS procedure compliance system (ERMI) that list the S/RID requirements for TWRS in each functional area and the documents that TWRS identified as implementing each S/RID (Phase 1 of the TWRS assessment). Also included are documents that were identified during this assessment as implementing project W-314 S/RIDs.

Task 2 evaluated the 16 TWRS program S/RID functional areas to identify areas that applied specifically to project $W-314$. The S/RIDs applicable to project W-314 were determined by evaluating each individual S/RID in each functional area against the scope of project $W-314$ from inception to the point at which it begins operation. The following project W-314 functional areas were then prioritized into three groups to allocate resources to the most critical items.

- Priority 1 S/RID functional areas contain requirements that pertain to activities done completely within the scope of project W-314 (engineering, quality assurance, and construction).

- Priority 2 S/RID functional areas contain requirements that are partially satisfied at the TWRS level and partially at the project W-314 level (such as fire protection, configuration management, nuclear safety). 
- Priority 3 S/RID functional areas requirements are largely satisfied at the TWRS level and contain very few that apply to project W-314.

Task 3 consisted of an assessment of each functional area, in priority sequence, to further refine the set of S/RIDs that apply to project W-314. This task involved determining, for each S/RID requirement, a document used on the project that implemented the requirement. This is analogous to a Phase 1 assessment under the S/RID program but tailored specifically to project W-314. A matrix was developed to document the results. All the S/RIDs were found to have suitable implementing documents.

\section{PURPOSE}

This assessment of project W-314 for compliance with TWRS program S/RID requirements that apply to the project was conducted to aid in preparing for readiness reviews that will be conducted prior to obtaining $R L$ approval to operate. Not completing this assessment, and any corrective actions resulting from it, could jeopardize the planned operations start date.

\section{DESCRIPTION}

The S/RID assessment was subdivided into three tasks that are described in this section.

\section{Task 1}

The primary source material obtained for this assessment is a current "Requirements by Outline Report" from the TWRS ERMI for all 16 S/RID functional areas that apply to the TWRS program. These reports list each S/RID requirement source, the text of the requirement, and implementation documents that were found during the S/RID Phase 1 assessment for TWRS. Reference documents consisted 
of current copies of the major documents that demonstrate the implementation of S/RIDs on project W-320 (Task 3). Reference documents were obtained from Project W-314 document control to ensure current revisions were used.

\section{Task 2}

Task 2 is a listing of S/RID functional areas that apply to project W-314 in order of priority. Priorities are needed so that greater emphasis can be given to the functional areas that directly apply to the scope of the project, such as engineering and construction.

Three priorities were established. Priority 1 functional areas contain activities that are completely within the scope of the project. As an example, the S/RID functional area of engineering contains requirements pertaining to the design process from identification of requirements through the establishment of criteria for acceptance testing. All these activities are performed by project personnel and are within the scope of the project from its inception until RL approval is obtained for operation. The conclusion that engineering is a Priority 1 functional area was confirmed by reviewing each of the 43 individual requirements listed in the TWRS S/RID database (ERMI) and asking the question, "Does this requirement apply to project W-314?" All 43 requirements apply. Priority 1 functional areas are those for which all the TWRS requirements also apply at the project level. Three functional areas became Priority 1: engineering, construction, and quality assurance. Table 1 summarizes the data.

Priority 2 functional areas were grouped using the same approach. This group contains functional areas for which the S/RID requirements apply to both the TWRS program level and the project W-314 level. As an example, configuration management contains requirements that must be implemented at the project level, such as the need to have an equipment database that is controlled and contains certain information. However, the configuration management functional area also contains requirements that are satisfied at the TWRS program level without specific 
application to project $\mathrm{W}-320$, such as having an overall facility (program) configuration management program plan. Table 1 shows the Priority 2 group of nine functional areas with the results of which S/RIDs apply.

The number of S/RIDs applicable to W-314 in Table 1 may appear small especially in fire protection, occupational safety and health (OS\&H) and operations. For fire protection, many requirements do not apply because the project does not modify fire protection systems or add new building. Thus, the existing TWRS Phase 1 assessment should adequately address this functional area. Note that the tie between the safety analysis report (B10) and TWRS fire hazards analysis (S/RID 12.3, RLID 5480.7, Section 6.2), currently indicated as "discrepant" in the TWRS S/RID database, was not re-addressed at the project level.

The majority of the OS\&H and operations requirements that are not applicable to W-314 are already addressed at the TWRS level. The S/RIDs are implemented in IP-0842 procedures already listed in the TWRS S/RID database (ERMI).

Priority 3 functional areas are those for which few, if any, S/RID requirements apply to project $W-314$. Four of the 16 applicable functional areas are in the Priority 3 group.

\section{Task 3}

Task 3 carried the data accumulated during Task 2 to the next step-determining if the documents used by project W-314 to establish requirements comply with the S/RIDs that were tailored to the project level. Beginning with the Priority 1 functional areas, each individual S/RID applicable to the project was reviewed with the intent of finding if a document used by the project existed that showed compliance with the S/RID. Documents reviewed include design requirements document, system safety program plan, project execution plan, quality assurance plans, TWRS procedures (found in HNF-IP-0842 and HNF-PRO-XXX documents), and engineer/constructor (Fluor Daniel Northwest) practices, and other project 
documents. The results are summarized in the tables shown in Appendix A. The tables are arranged in the same order as the functional areas in Table 1.

The Task 3 assessment found that all the Priority 1, 2, and 3 S/RID requirements were implemented in project $\mathrm{W}-314$ documents. 
PROJECT W-314

S/RID ASSESSMENT PRIORITY LISTING

TABLE 1

\begin{tabular}{|c|c|c|c|c|c|c|}
\hline \multicolumn{3}{|r|}{ FUNCTIONAL AREA } & \multicolumn{4}{|c|}{ S/RIDS APPLICABLE TO W-314? } \\
\hline No. & Ident. & Title & Yes & No & Total & $\%$ Applicable \\
\hline \multicolumn{7}{|c|}{ Priority 1} \\
\hline 7 & EN & Engineering & 43 & 0 & 43 & 100 \\
\hline 8 & $\mathrm{cs}$ & Construction & 28 & 0 & 28 & 100 \\
\hline 2 & QA & Quality Assurance & 9 & 0 & 9 & 100 \\
\hline \multicolumn{7}{|c|}{ Priority 2} \\
\hline 3 & $\mathrm{CM}$ & Configuration Management & 21 & 31 & 52 & 40 \\
\hline 19 & $\mathrm{OH}$ & Occupational Safety and Health & 99 & 224 & 323 & 31 \\
\hline 16 & WM & Waste Management & 98 & 222 & 320 & 31 \\
\hline 18 & NS & Nuclear Safety & 17 & 44 & 61 & 28 \\
\hline 20 & EP & Environmental Protection & 29 & 307 & 336 & 9 \\
\hline 4 & TN & Training and Qualification & 10 & 91 & 111 & 9 \\
\hline 12 & FP & Fire Protection & 9 & 153 & 162 & 6 \\
\hline$\theta$ & OP & Operations & 12 & 212 & 224 & 5 \\
\hline 1 & MS & Management Systems & 6 & 142 & 148 & 4 \\
\hline \multicolumn{7}{|c|}{ Priority 3} \\
\hline 11 & RP & Radiation Protection & 1 & 212 & 213 & 0.5 \\
\hline 5 & EM & Emergency Preparedness & 2 & 110 & 112 & 2 \\
\hline 6 & Ss & Safeguards and Security & 0 & 16 & 16 & 0 \\
\hline 10 & MN & Maintenance & 0 & 6 & 6 & 0 \\
\hline 14 & ER & Environmental Restoration & 0 & 0 & 0 & 0 \\
\hline 15 & DD & Decontamination and Decommissioning & 0 & 0 & 0 & 0 \\
\hline 17 & RD & R \& D/Experimental Activities & 0 & 0 & 0 & 0 \\
\hline 13 & PT & Packaging and Transportation & 0 & 0 & 0 & 0 \\
\hline
\end{tabular}




\section{CONCLUSION}

The overall conclusion is that project W-314 complies with the applicable S/RIDs by having project documents that implement the S/RIDs. Some areas of weakness were identified that should be addressed prior to the readiness reviews. These concerns are listed below as recommendations resulting from this assessment as well as items rising from similar assessments.

\section{Recommendations}

1. Several of the available reference documents that were used to determine if S/RIDs were implemented were applicable to the conceptual stage of the project's design. Included are the Configuration Management Plan (Rev. 0), System Safety Program Plan (Rev. 0), and Interface Control Document (Rev. 0 ). Since these documents state they will be updated when needed, the project simply needs to ensure revisions are completed at the proper time. Also, when updating these or other project documents, the conversion of legacy procedures and manuals needs to be addressed. For example, WHC-CM-4-46 no longer exists; it has been replaced by a number of Project Hanford procedures.

2. Ensure that mechanisms are in place to keep the design baseline and the safety analysis consistent and current such as a Safety Equipment List. The design baseline includes design basis documents (DRD, FRD, PDS) plus design documents (drawings, specifications, calculations). 
HNF-3699, Rev. 0

APPENDIX A

PHASE 1 RESULTS

$$
\text { A - } 0
$$


HNF-3699, Rev. 0

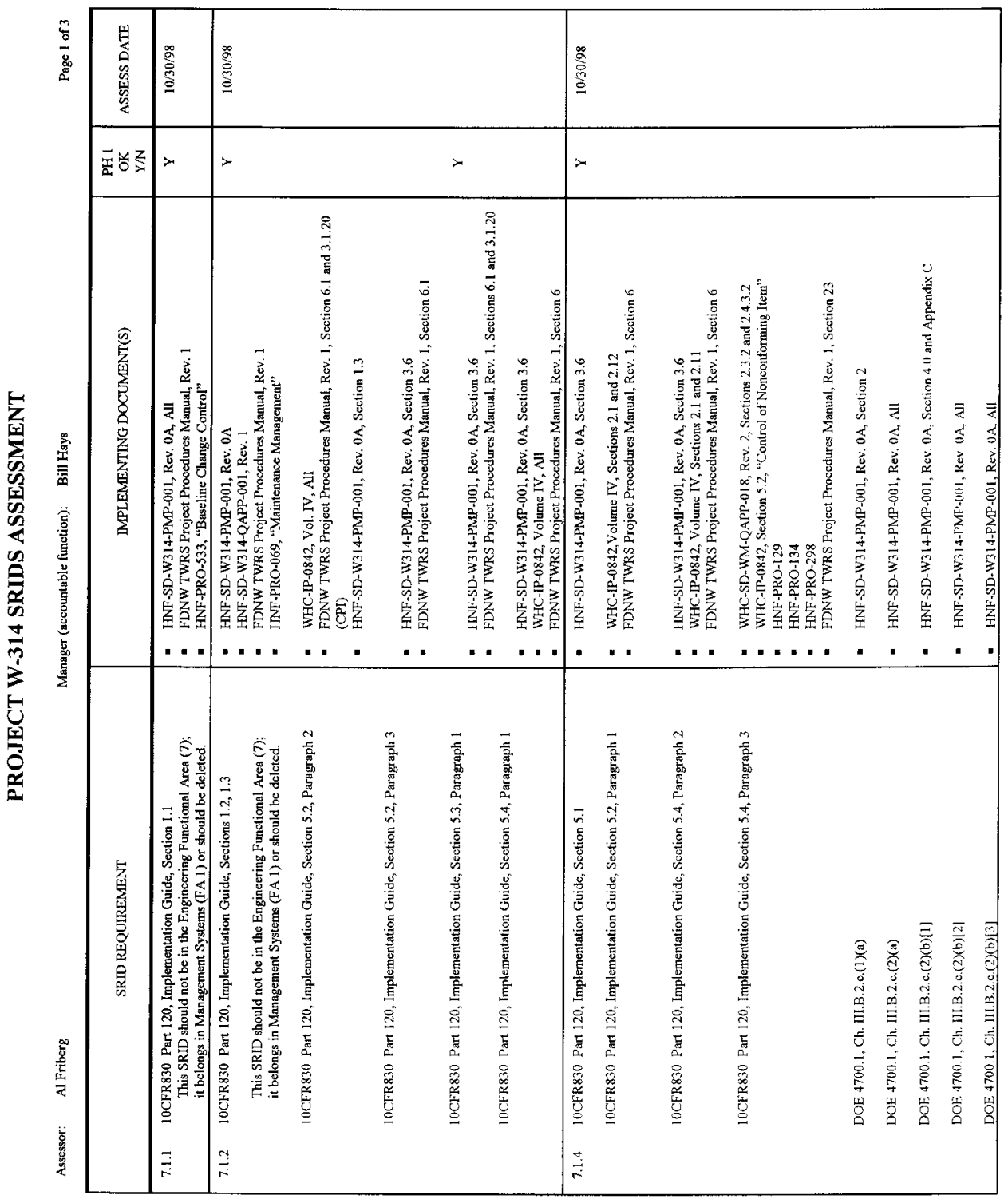




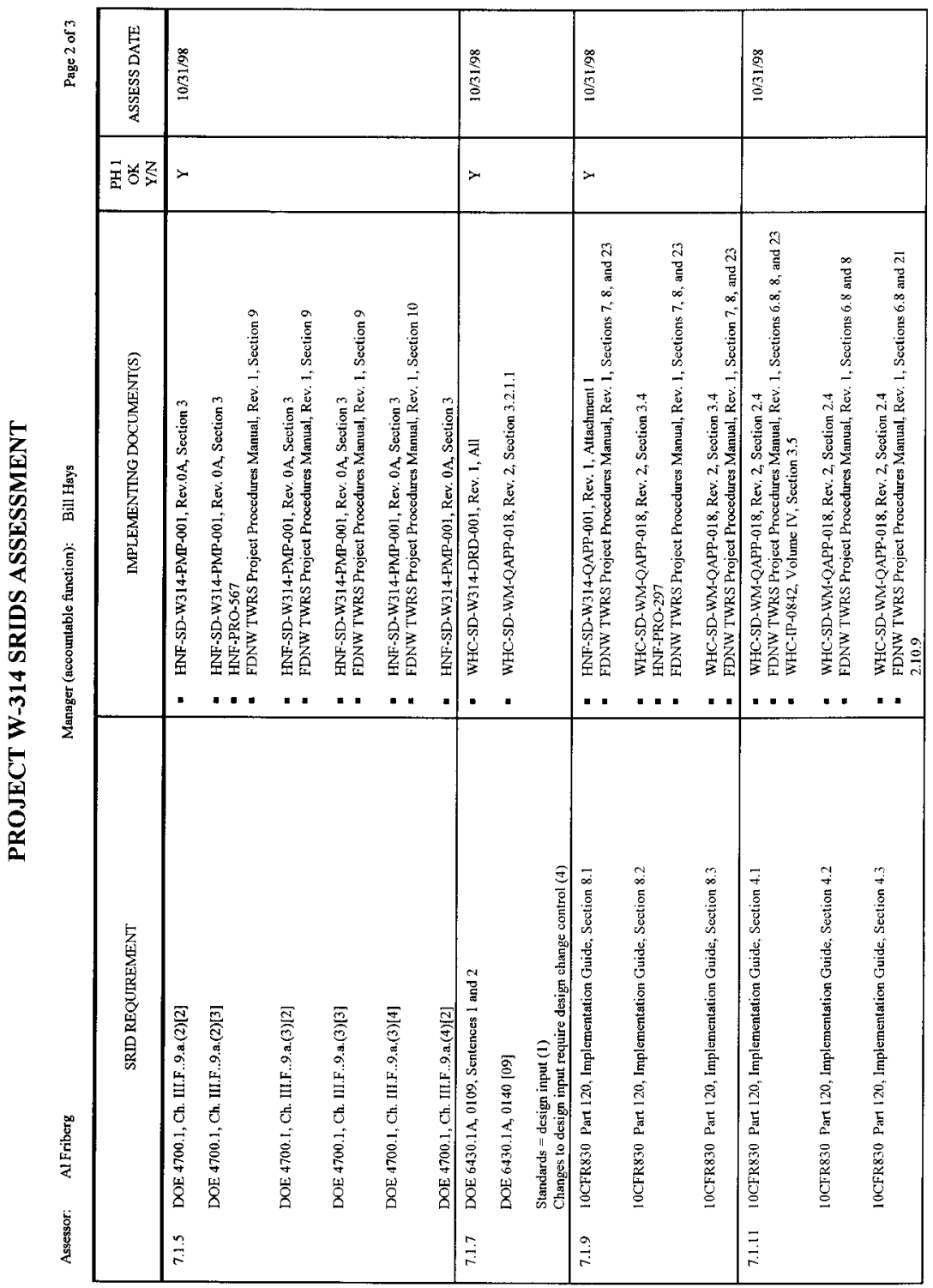


HNF-3699, Rev. 0

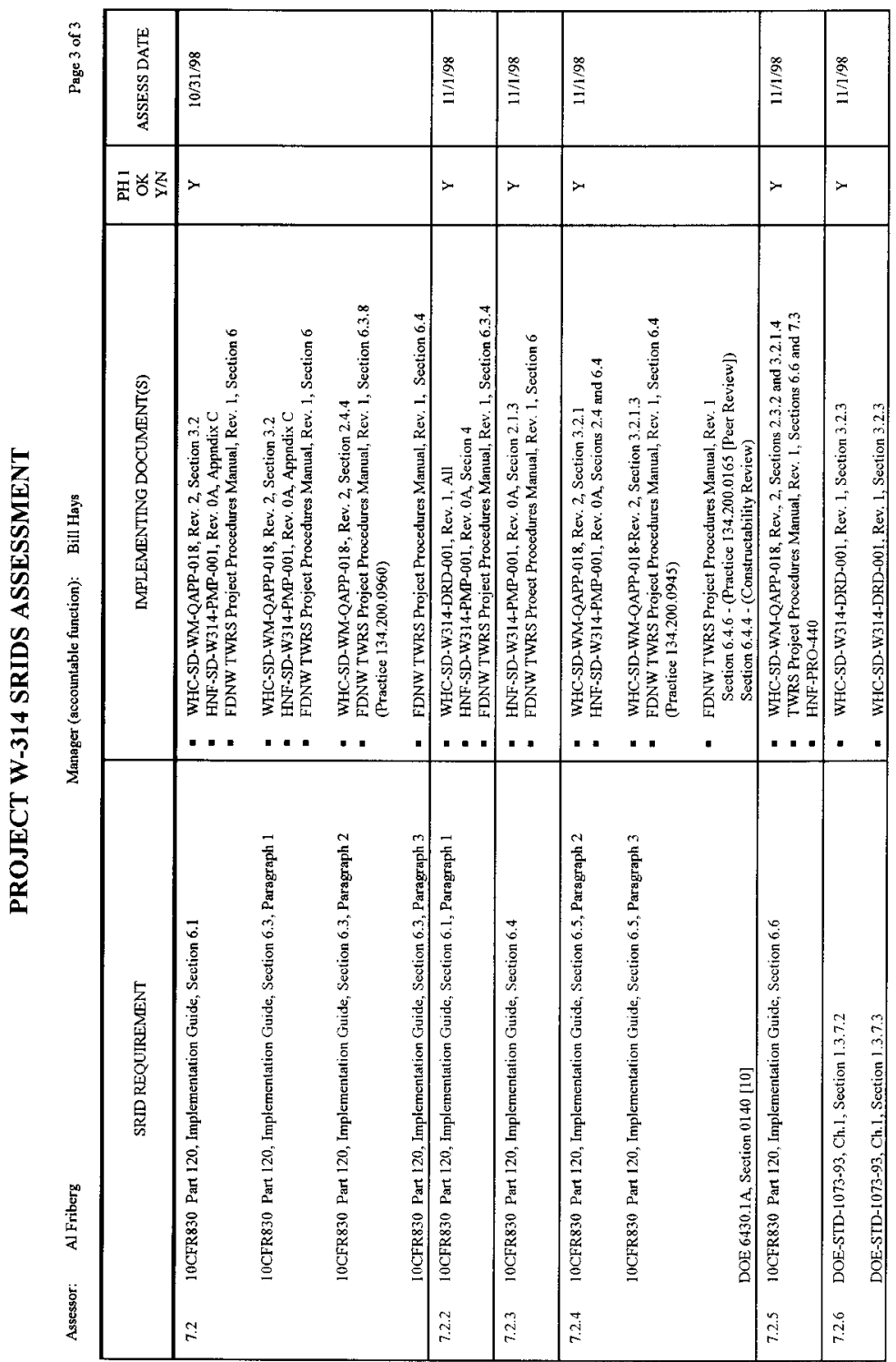


HNF-3699, Rev. 0

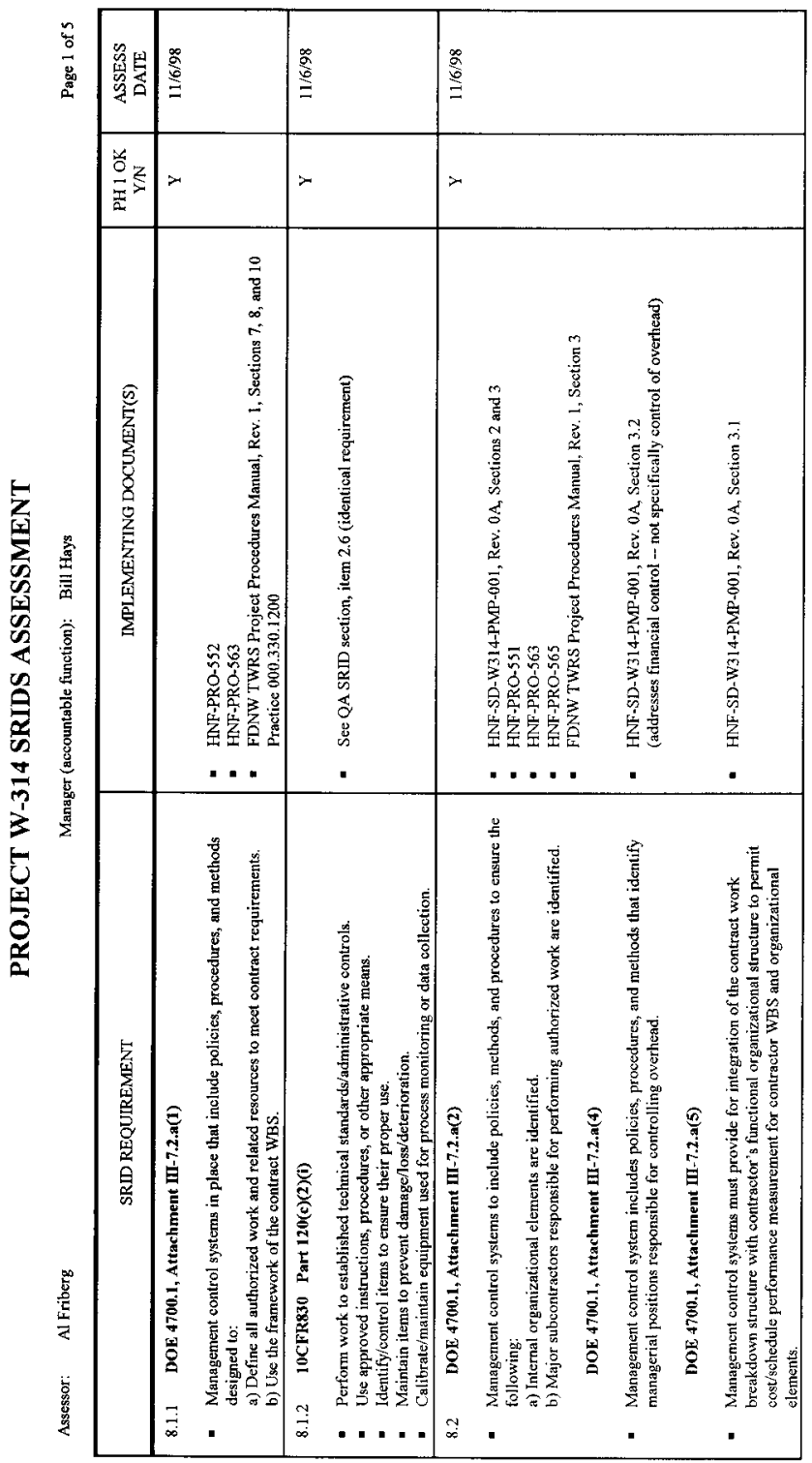


HNF-3699, Rev. 0

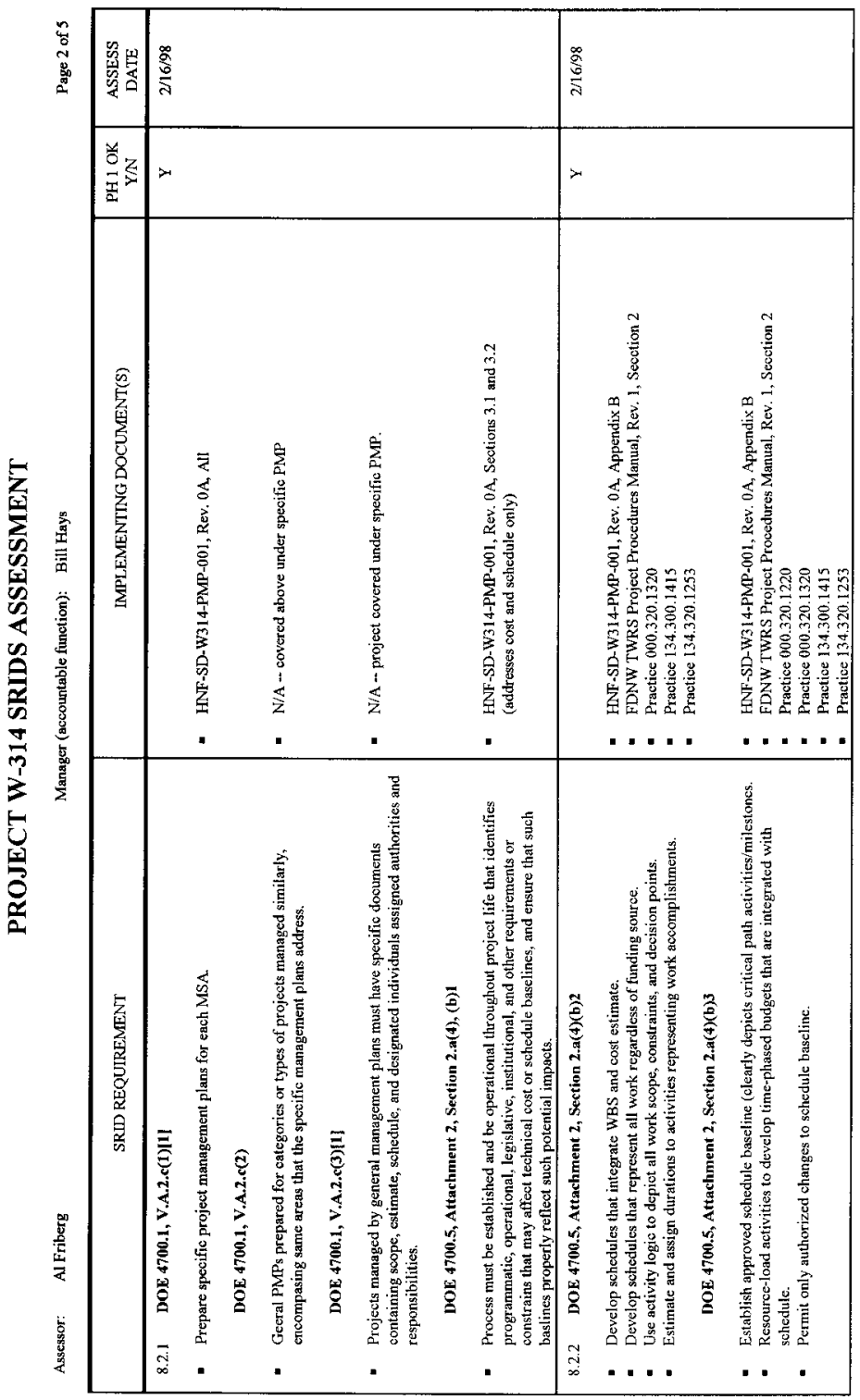


HNF-3699, Rev. 0

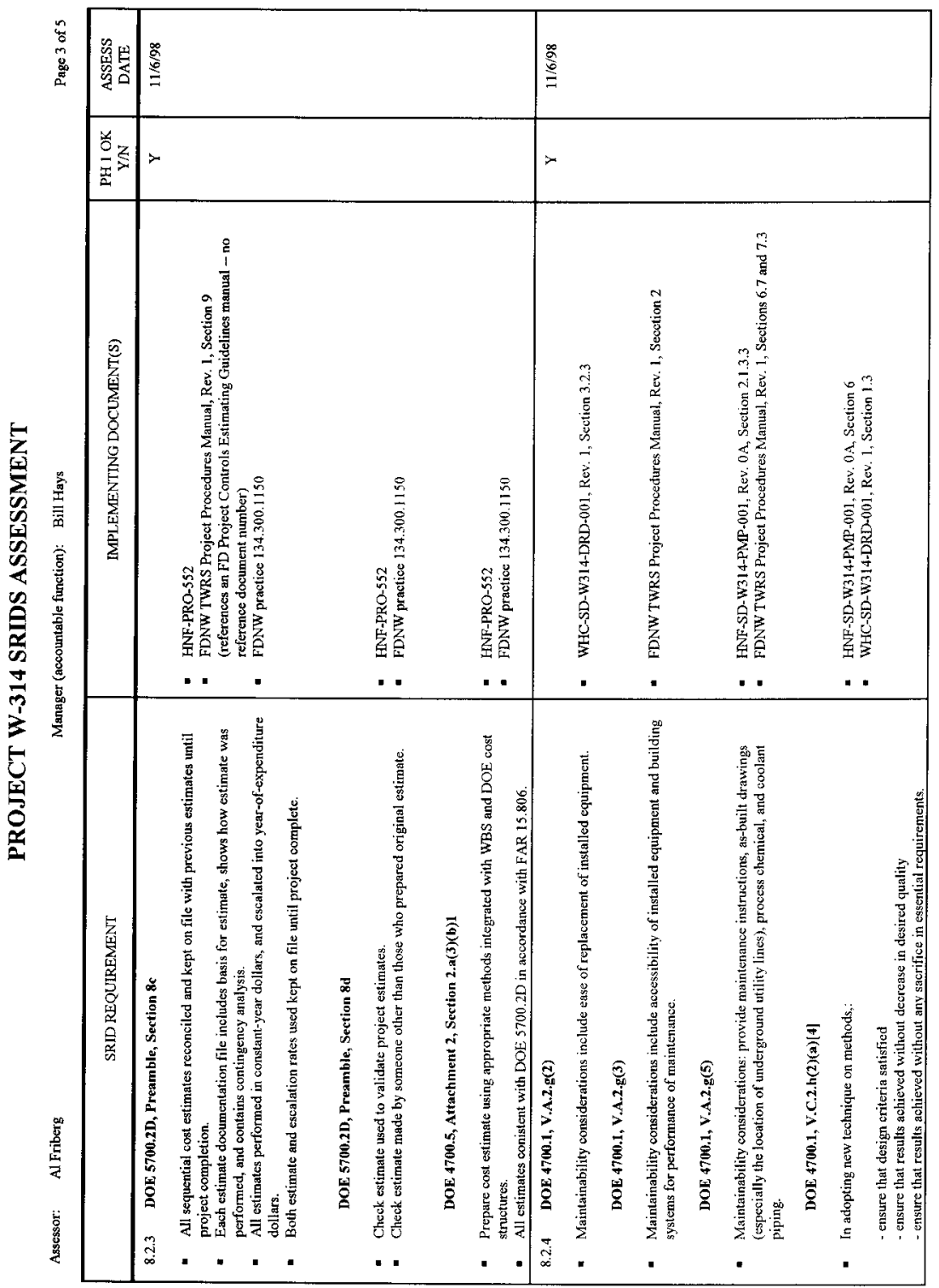


HNF-3699, Rev. 0






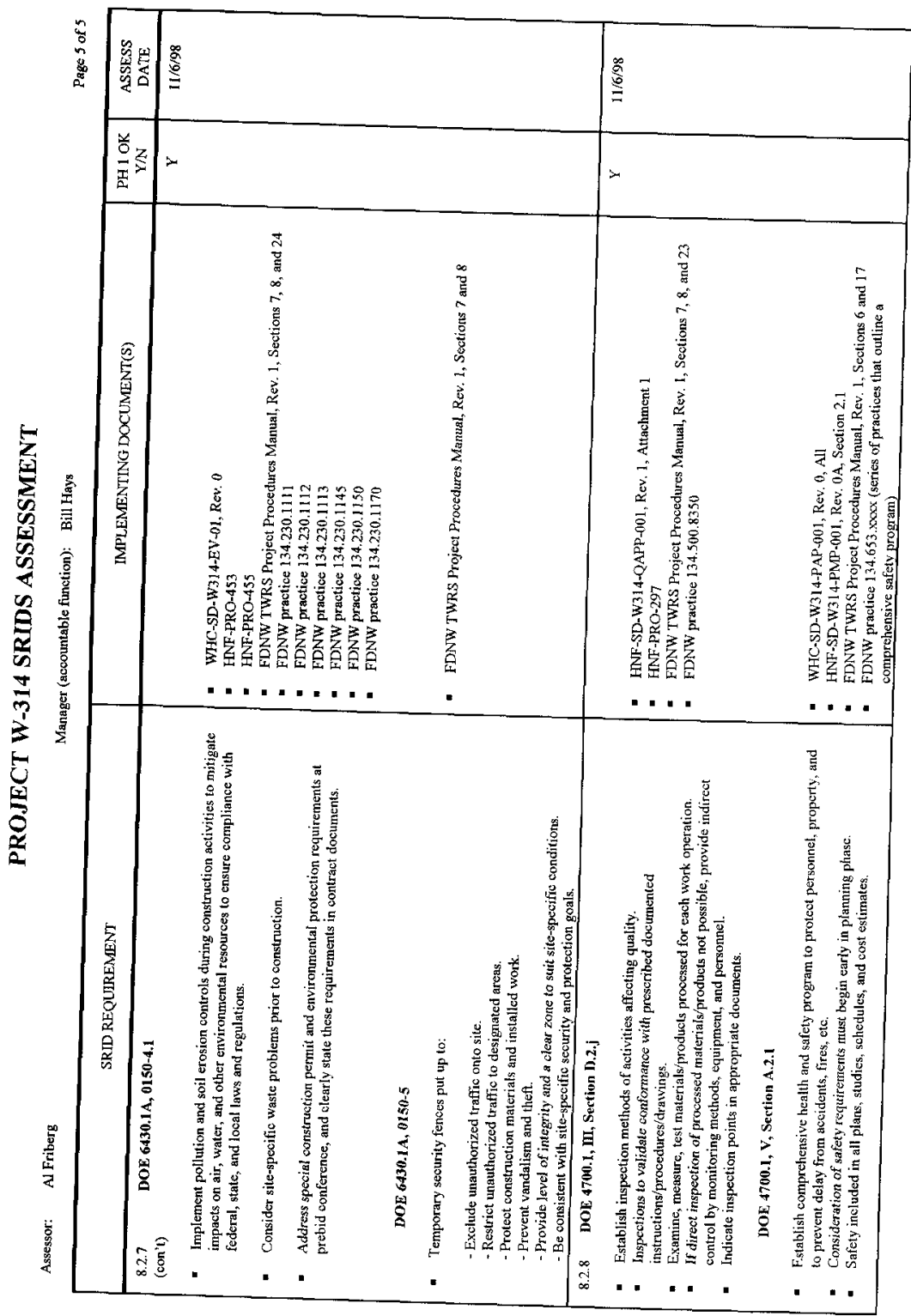




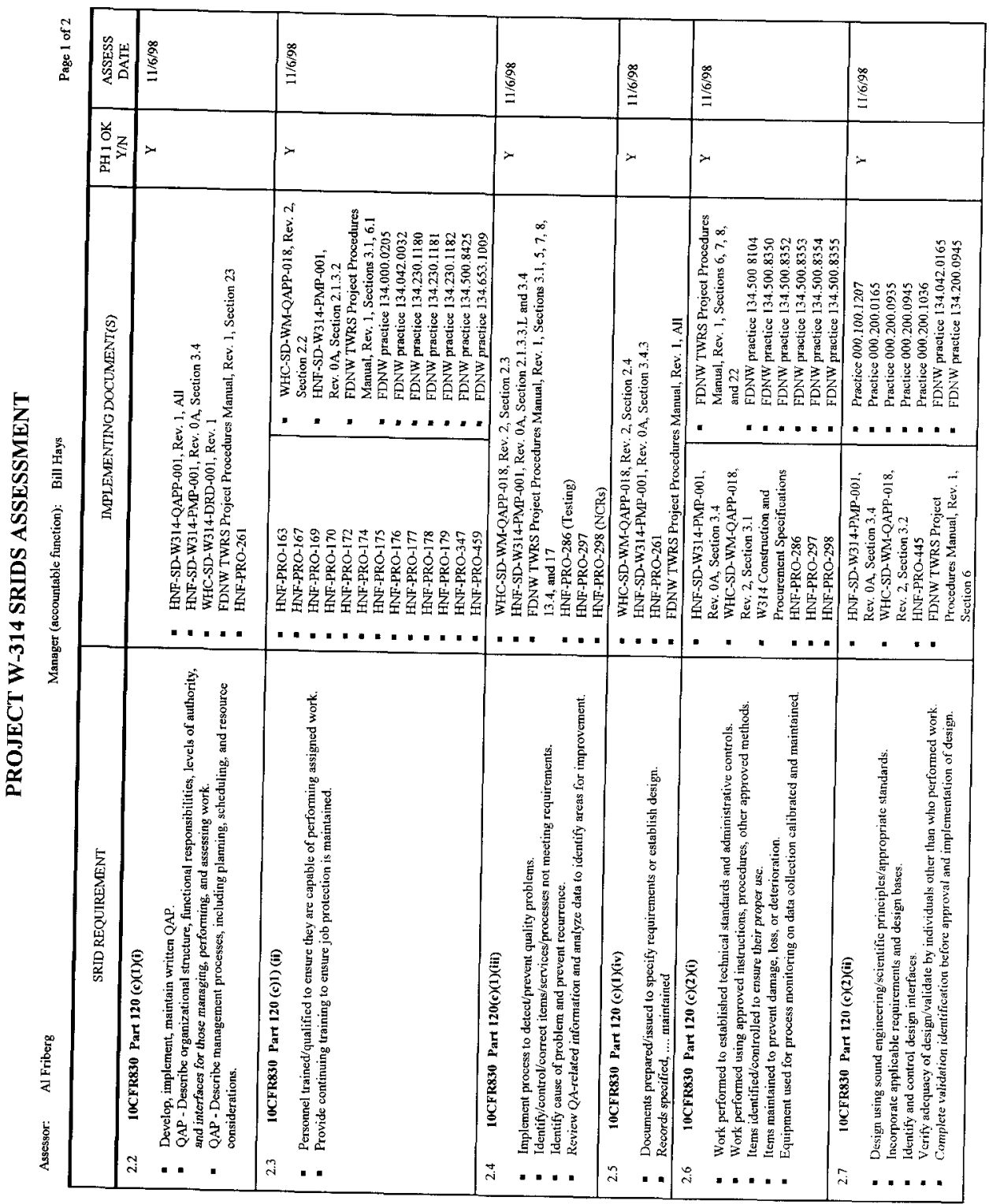


HNF-3699, Rev. 0

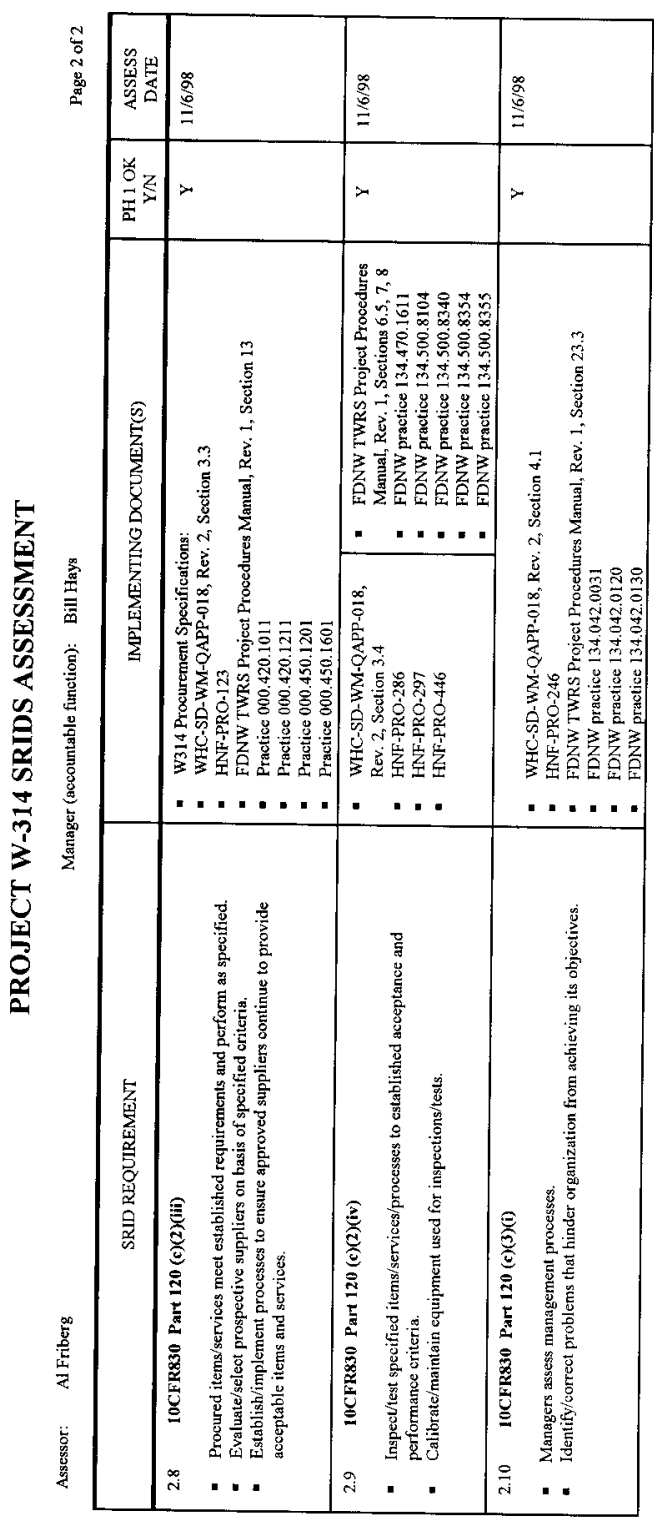

A -10 


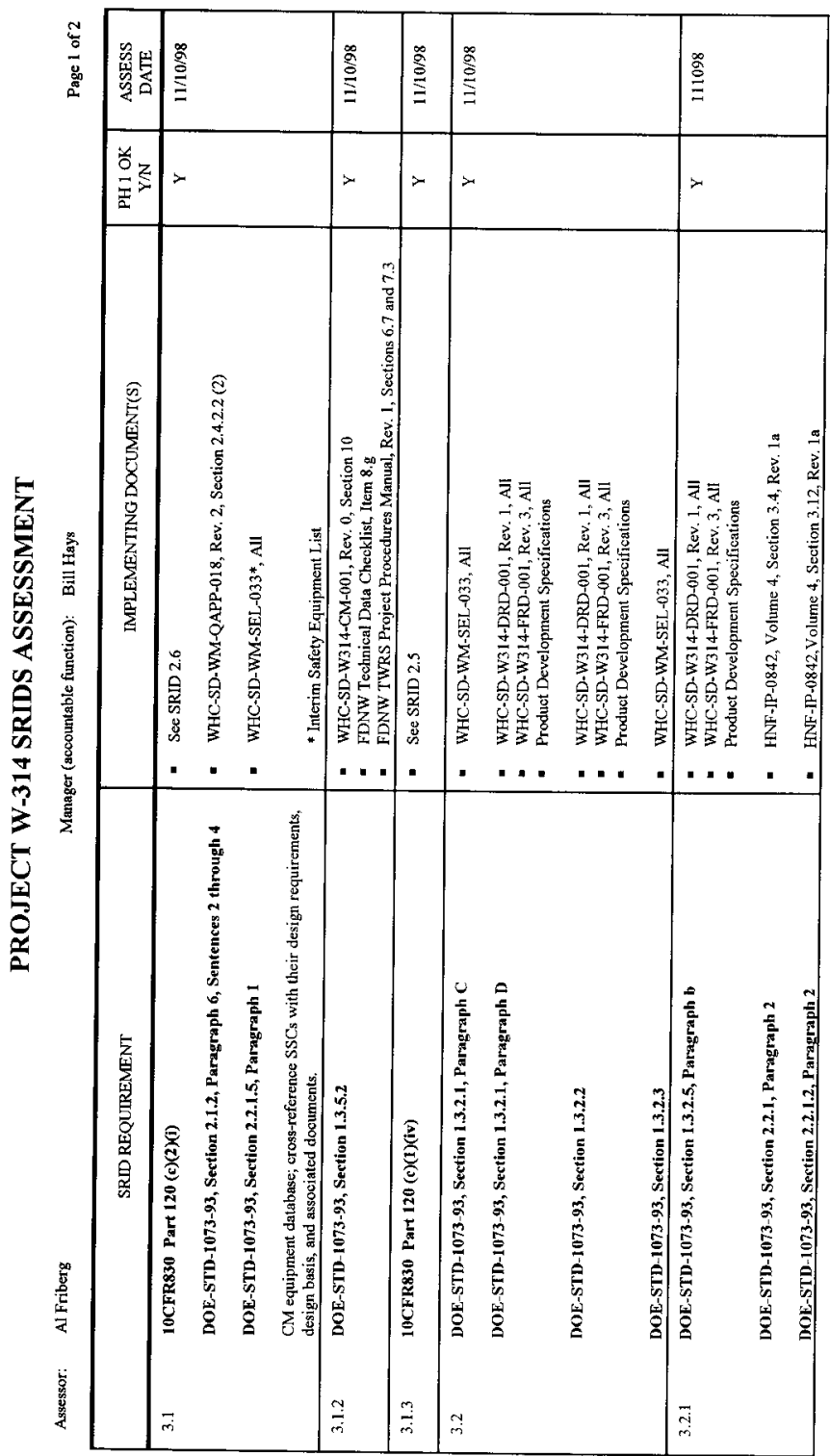


HNF-3699, Rev. 0

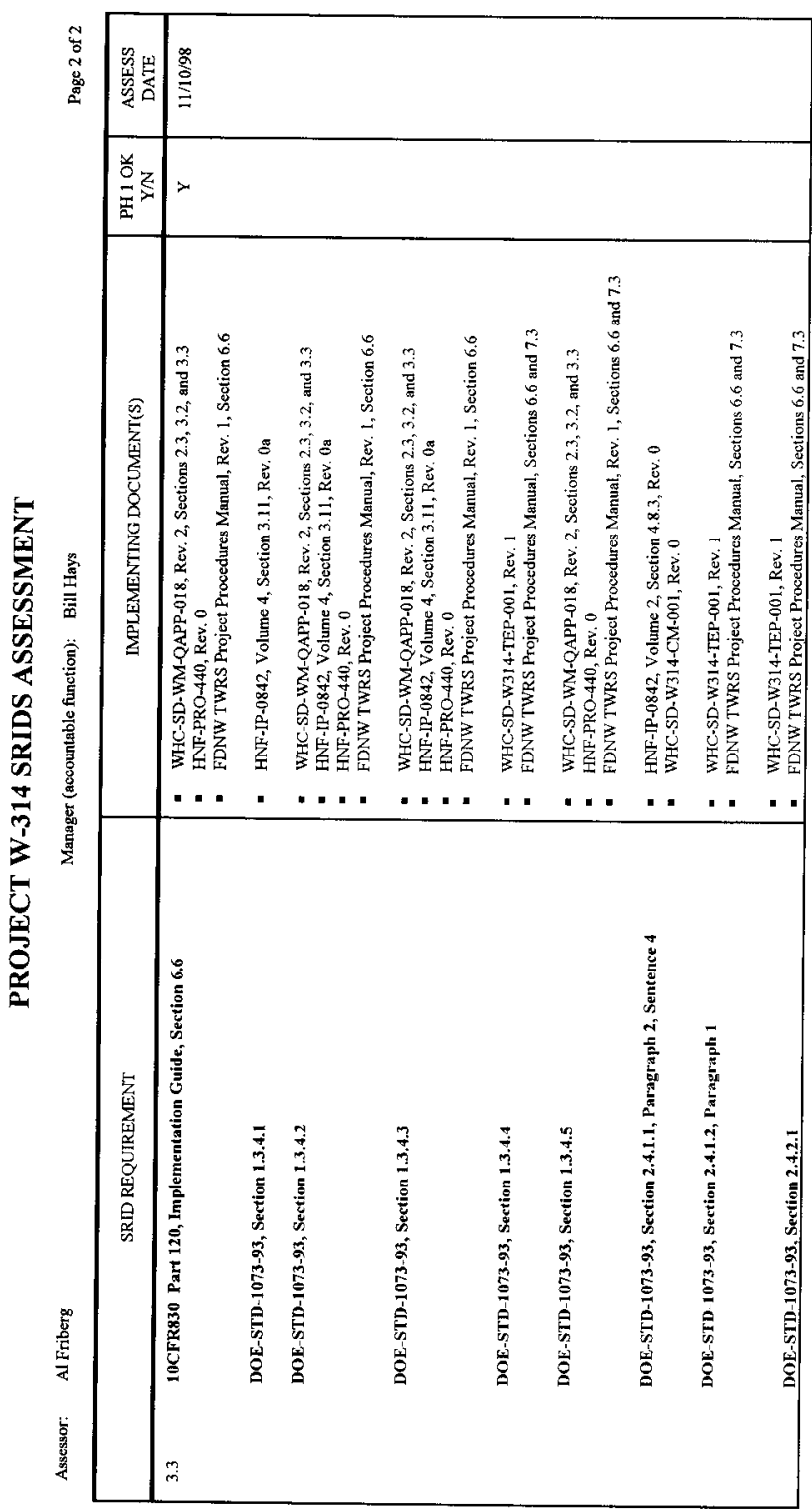


HNF-3699, Rev. 0






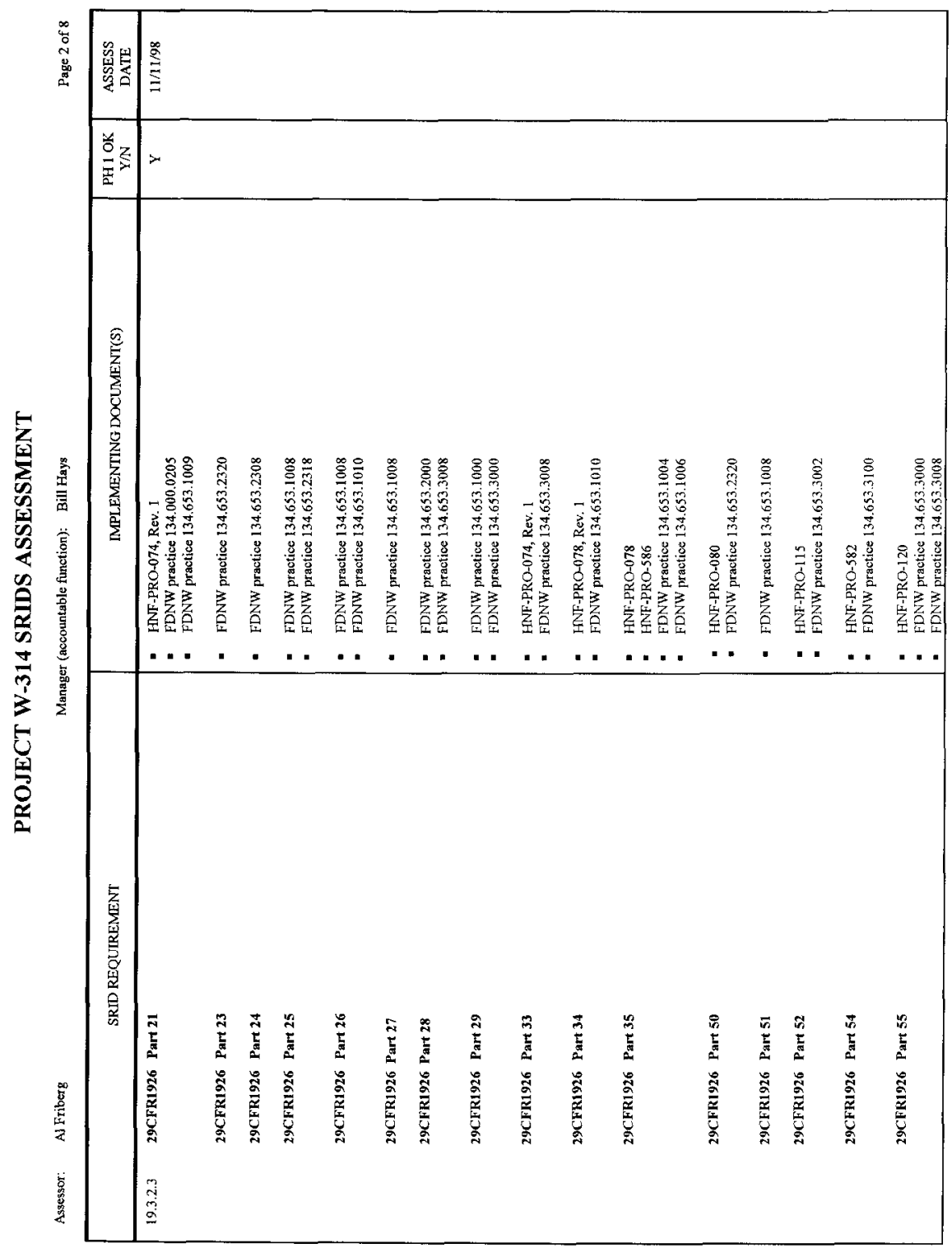


HNF-3699, Rev. 0

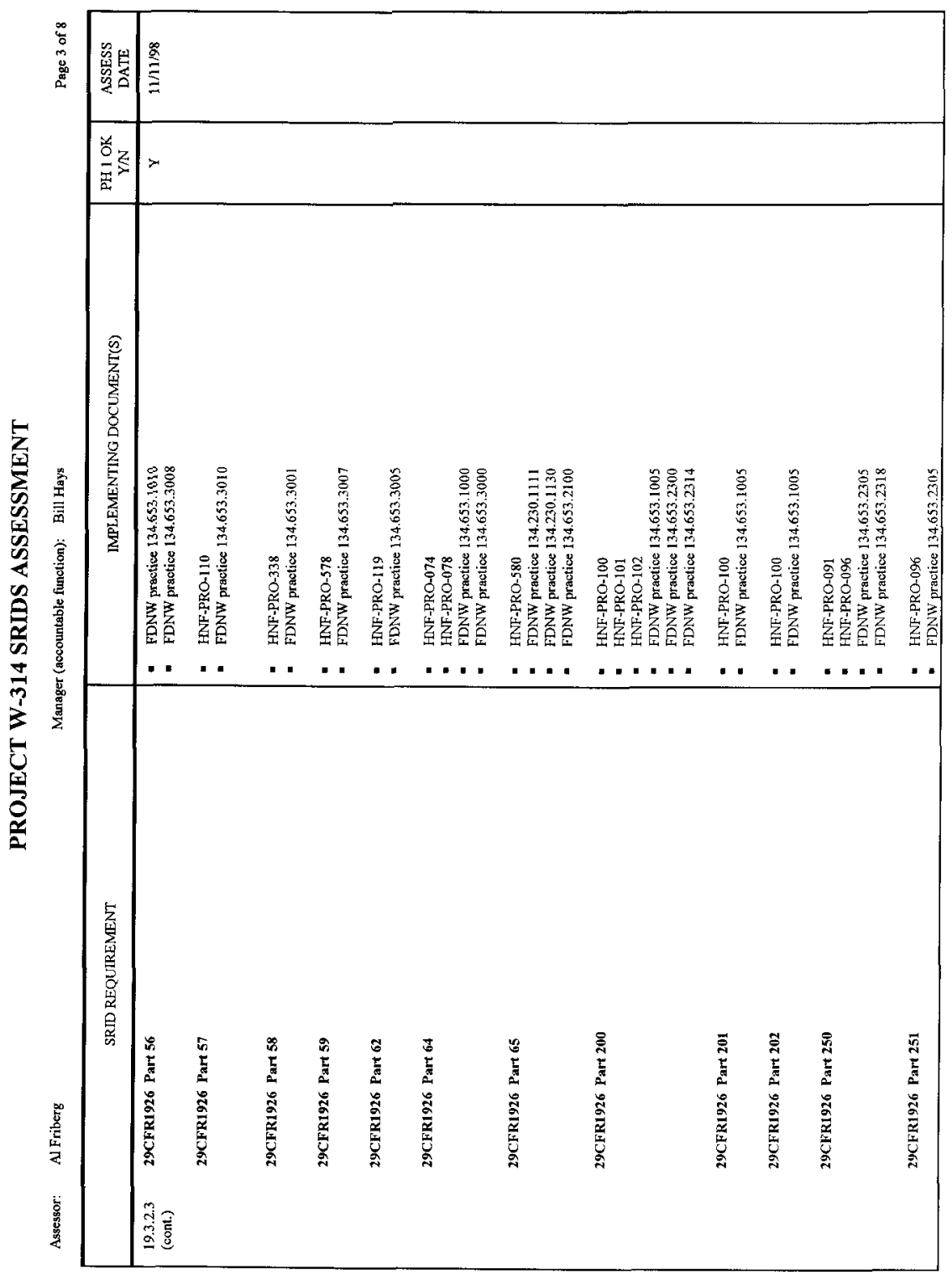


HNF-3699, Rev. 0

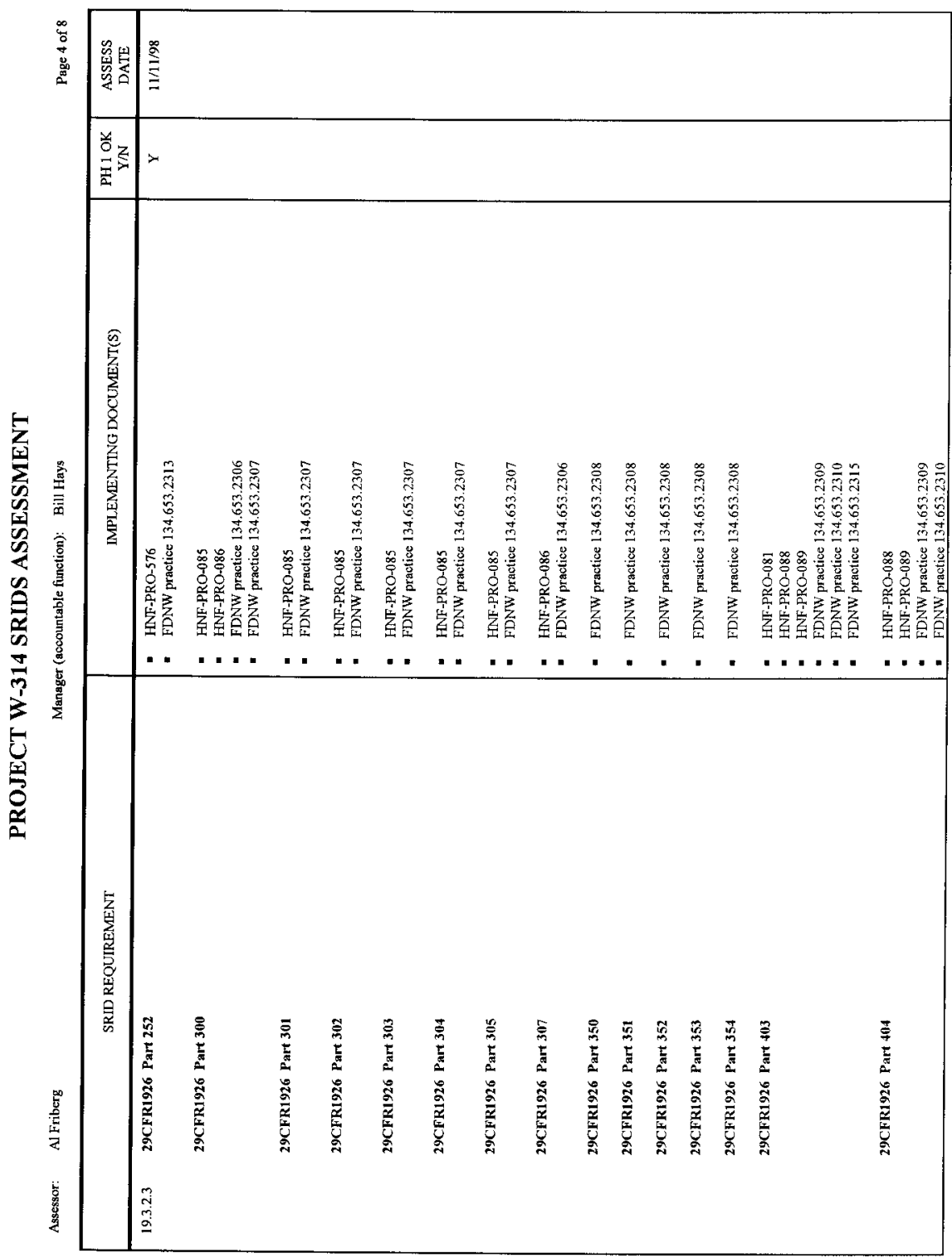


HNF-3699, Rev. 0

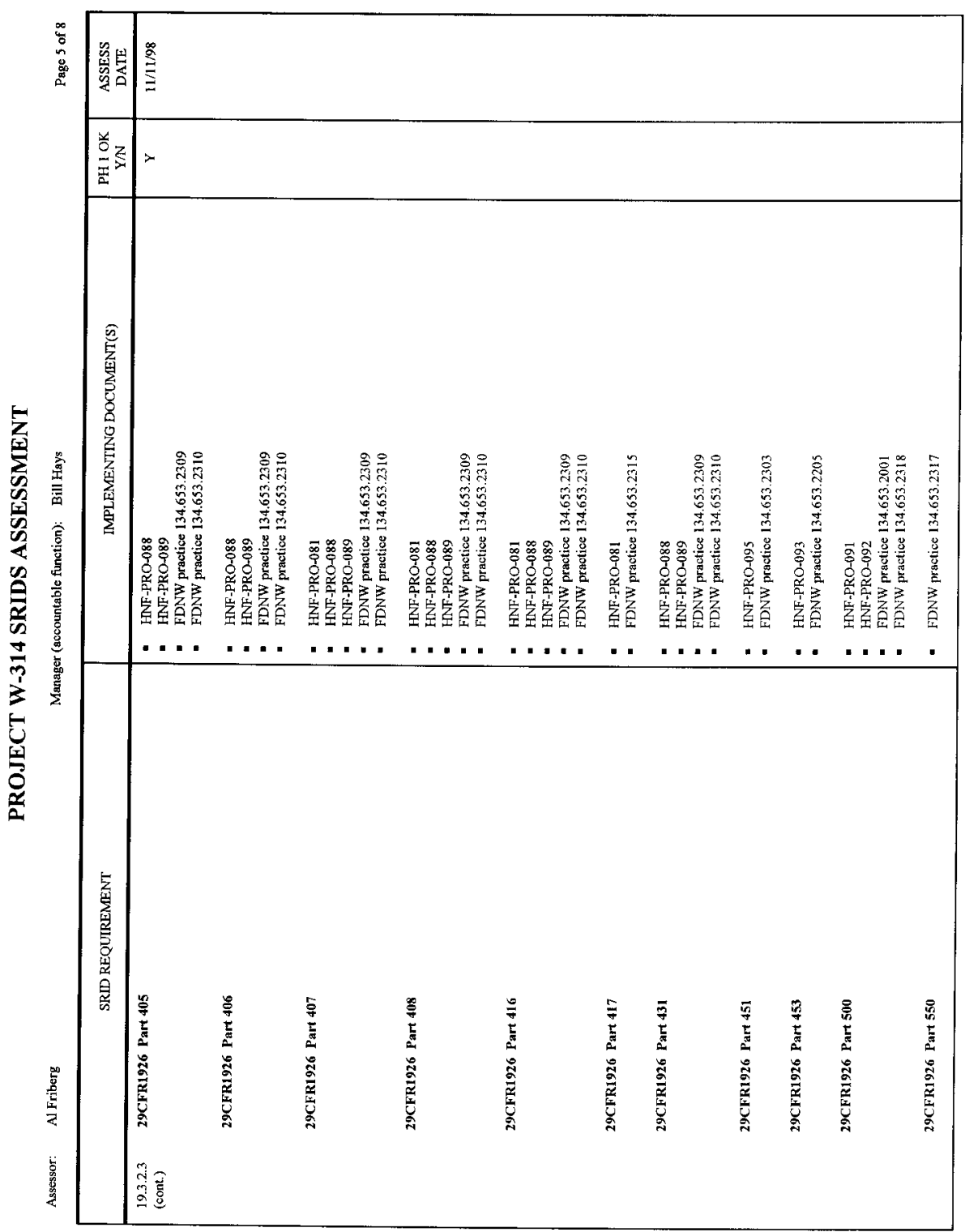


HNF-3699, Rev. 0

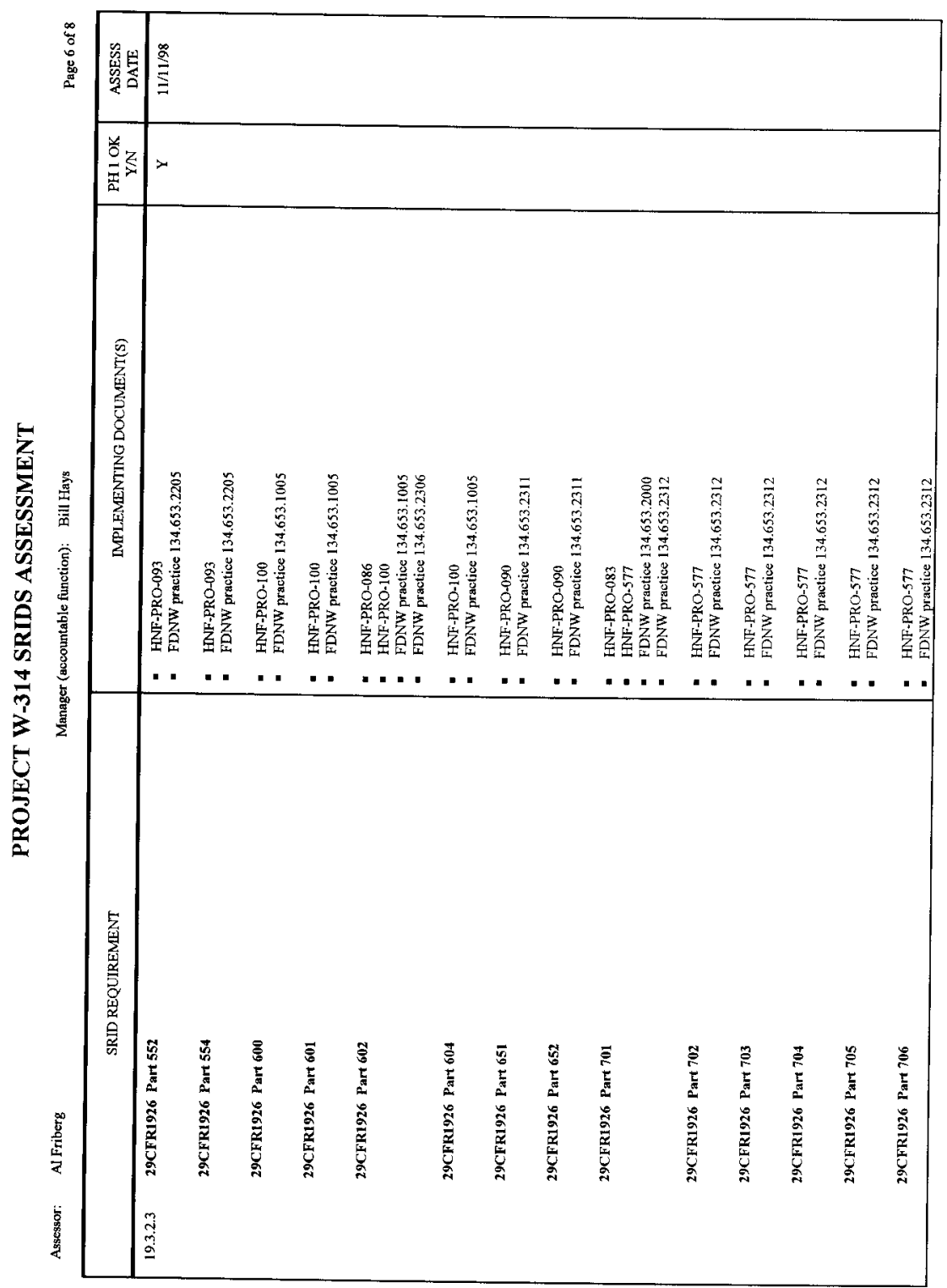


HNF-3699, Rev. 0

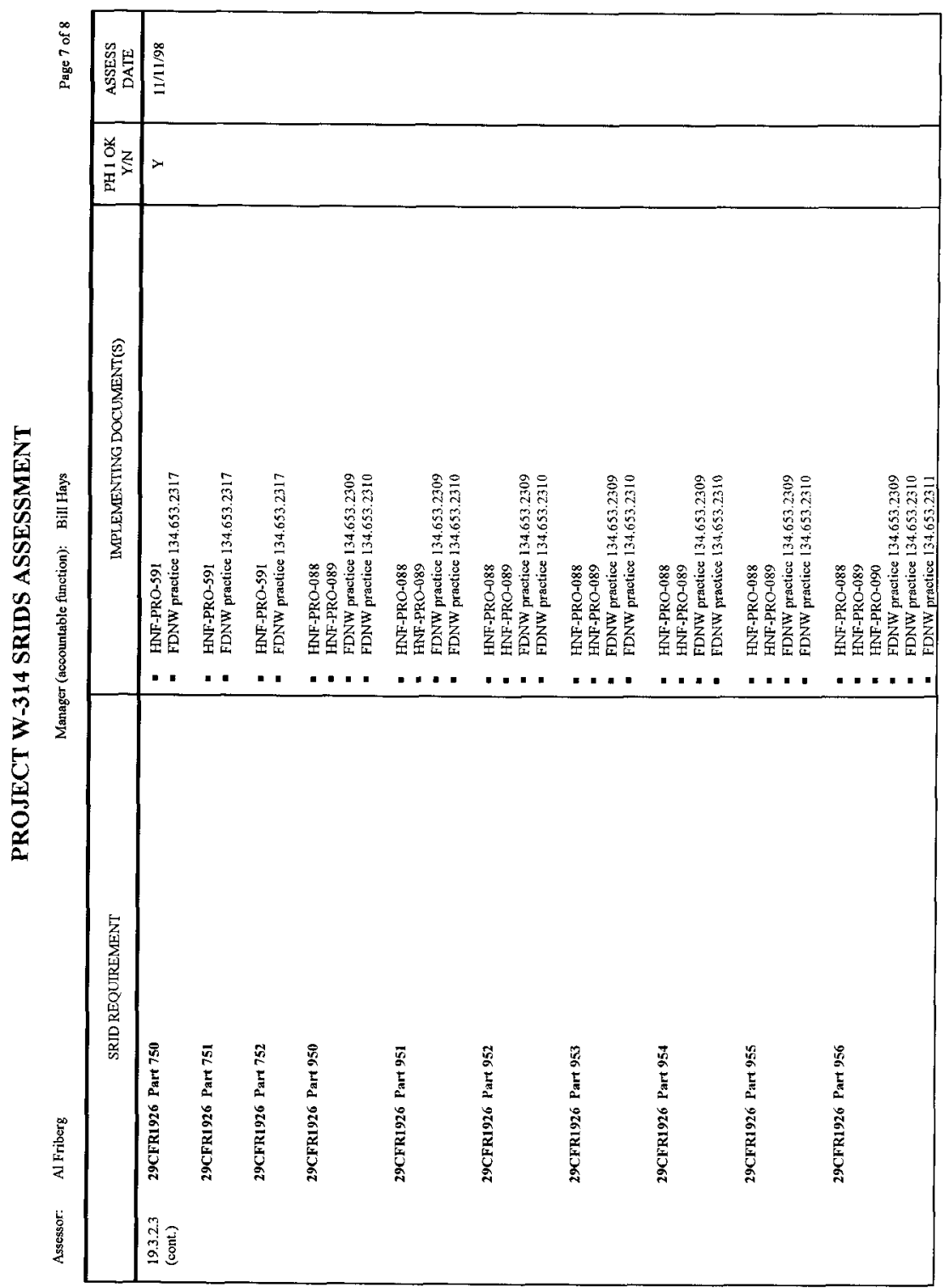


HNF-3699, Rev. 0

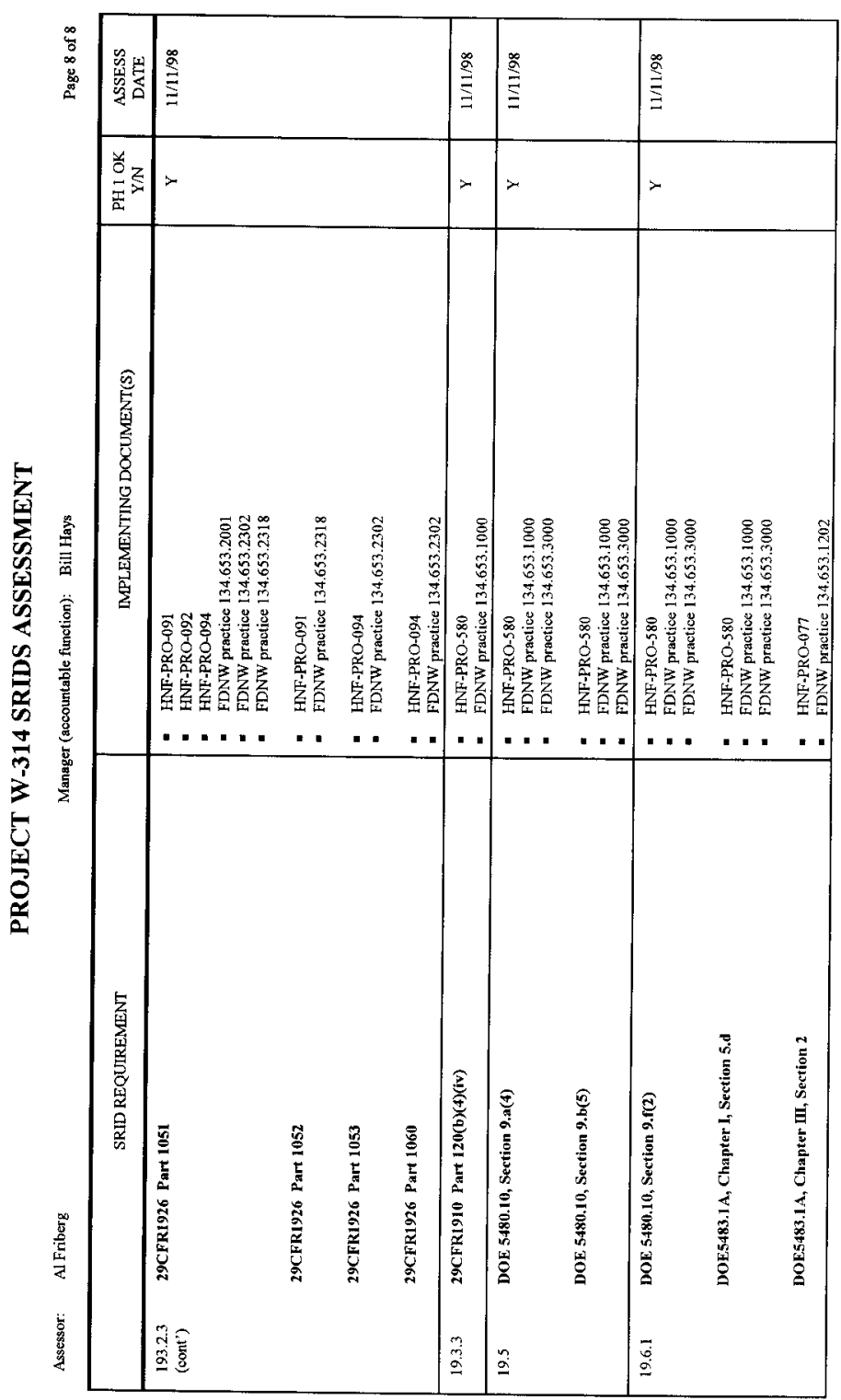


HNF-3699, Rev. 0

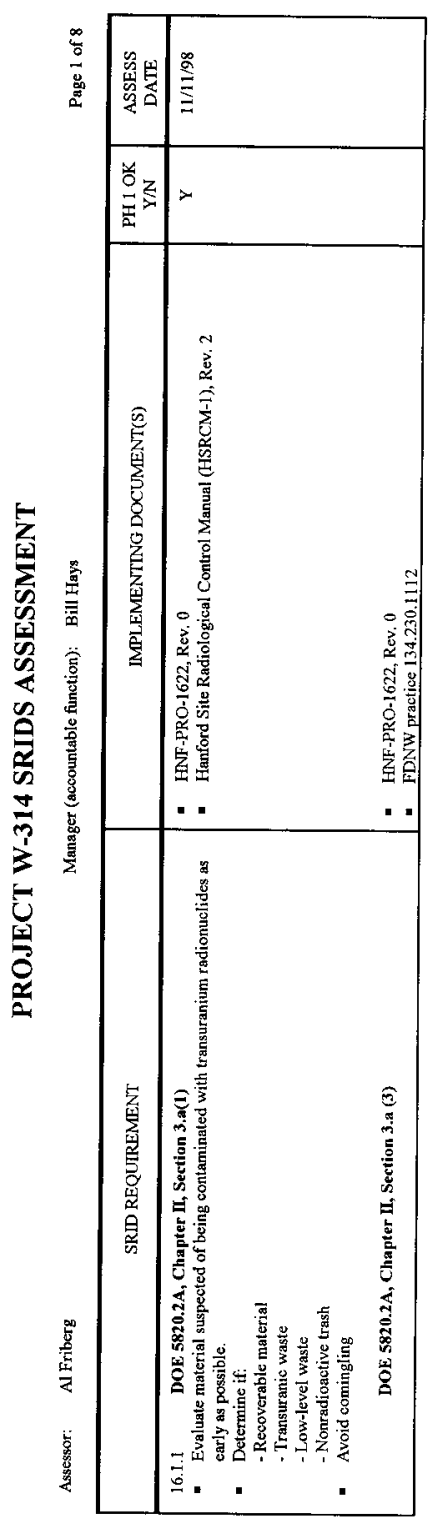


HNF-3699, Rev. 0

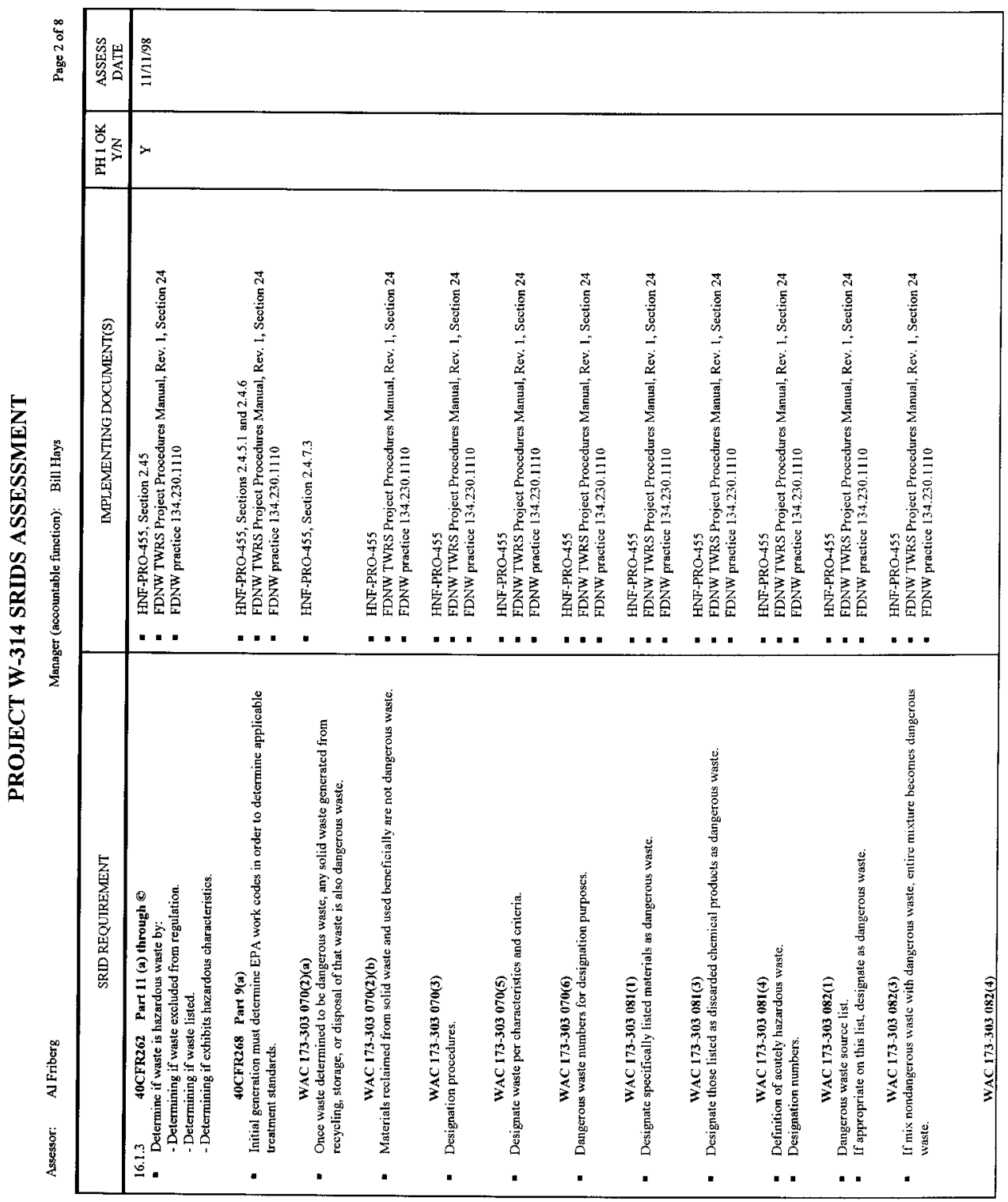


HNF-3699, Rev. 0

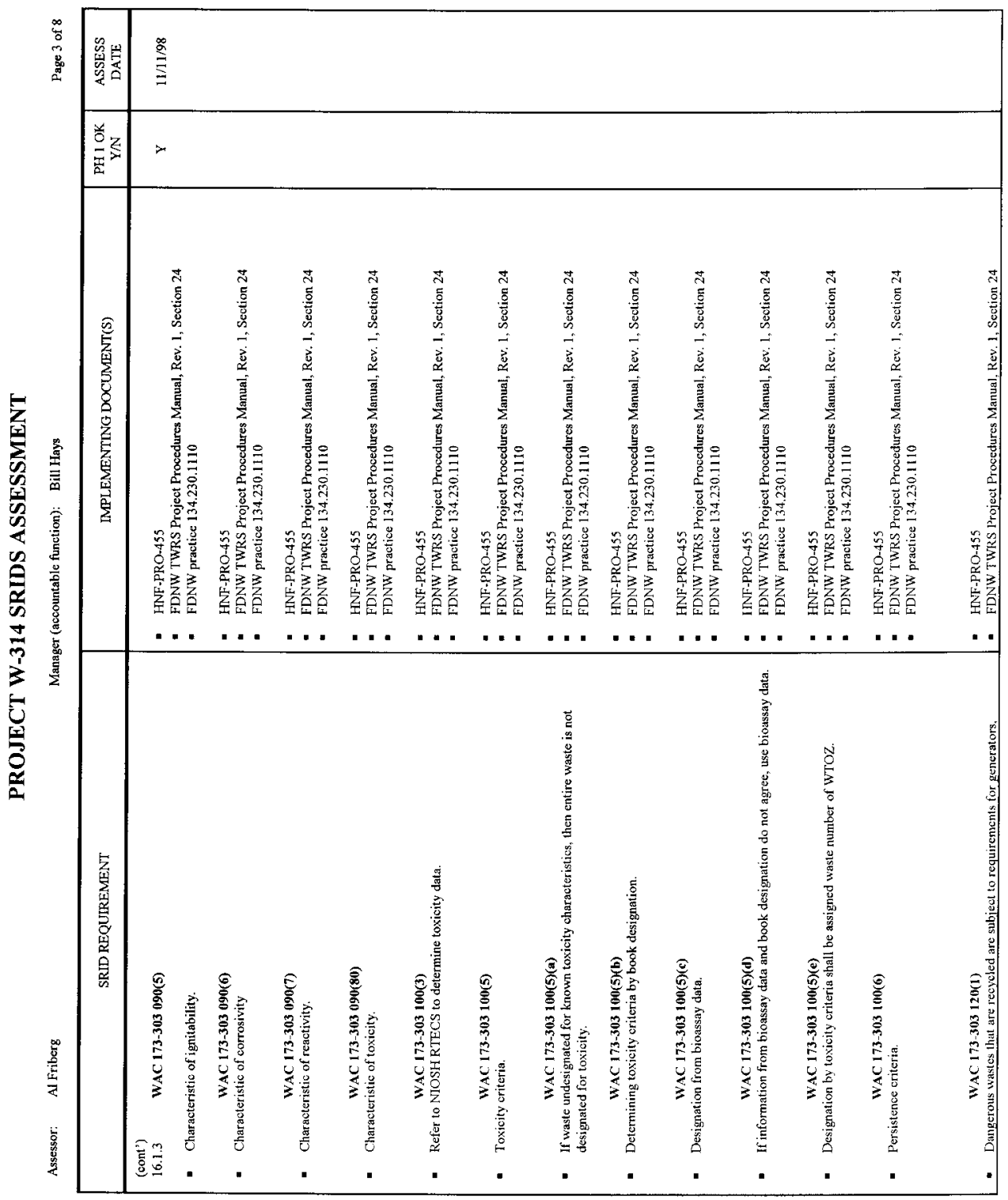


HNF-3699, Rev. 0

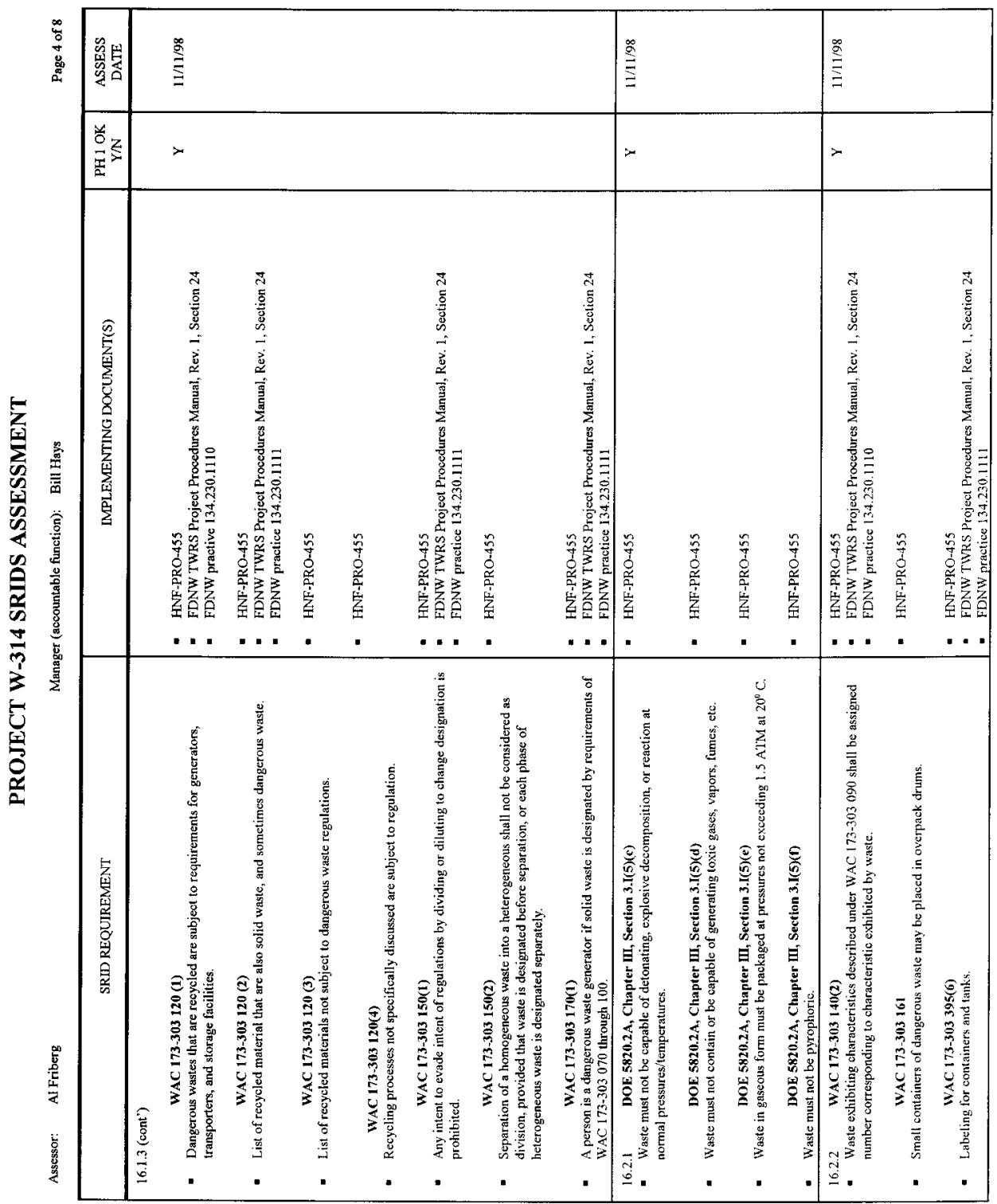




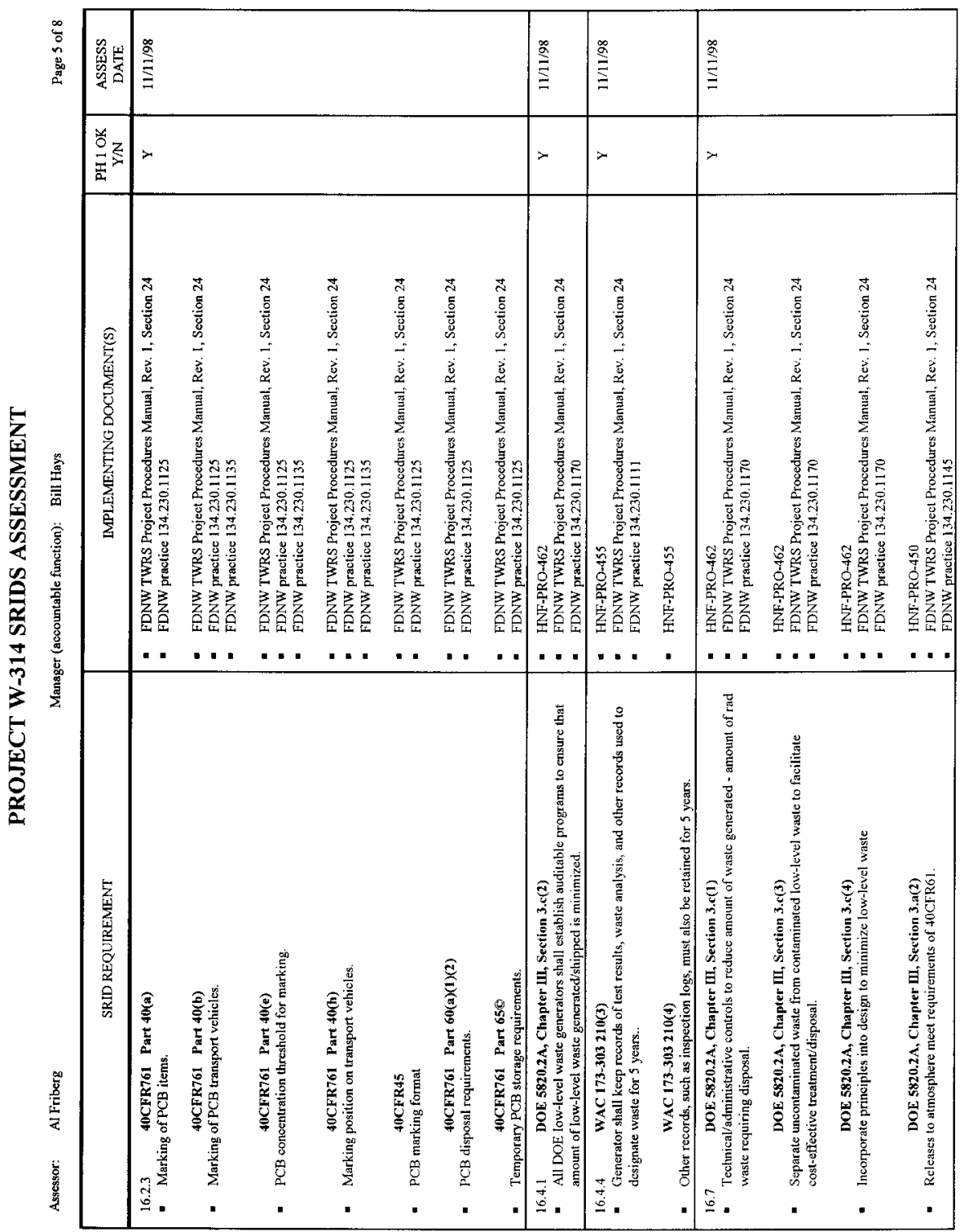


HNF-3699, Rev. 0




HNF-3699, Rev. 0

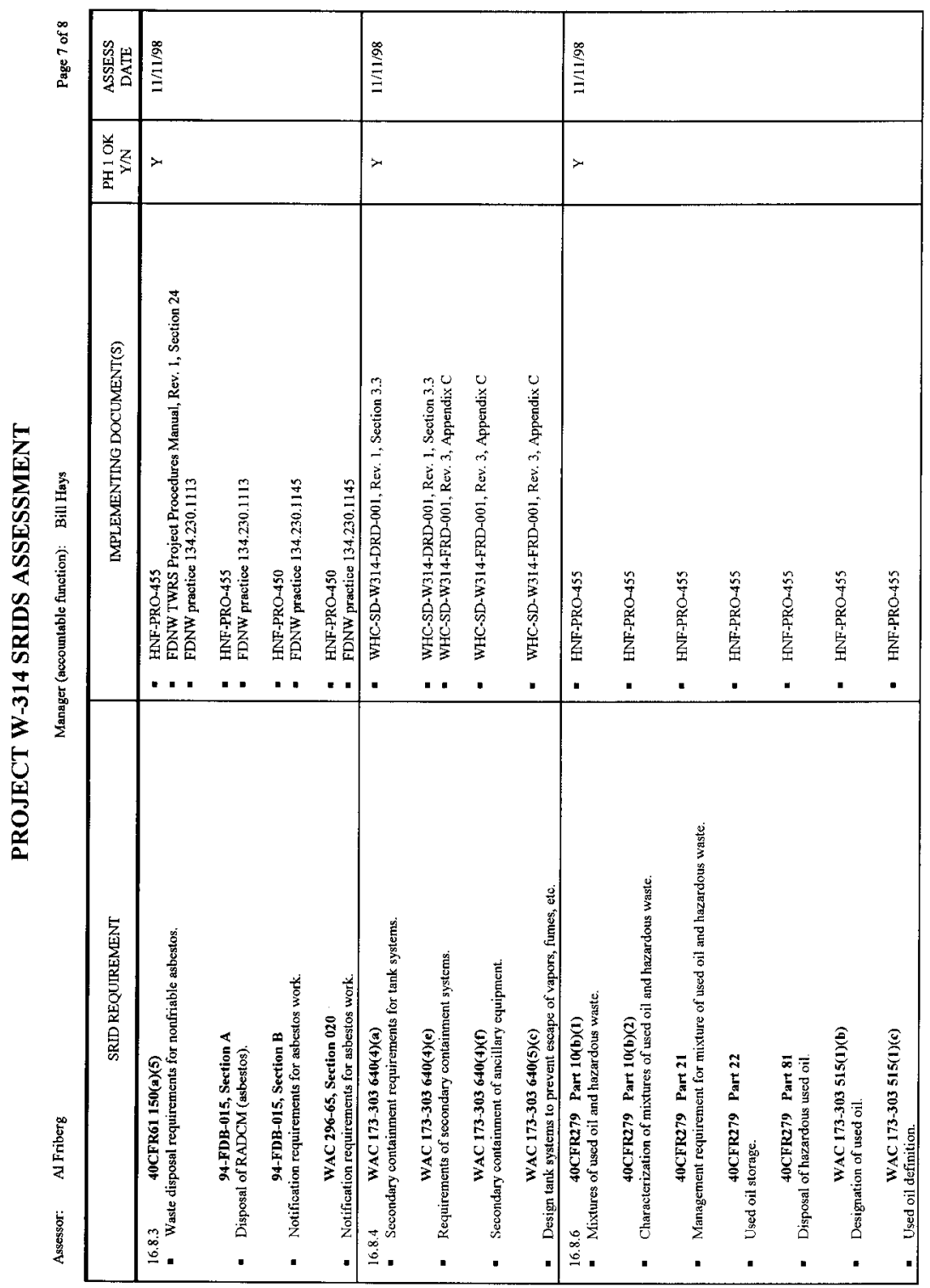


HNF-3699, Rev. 0

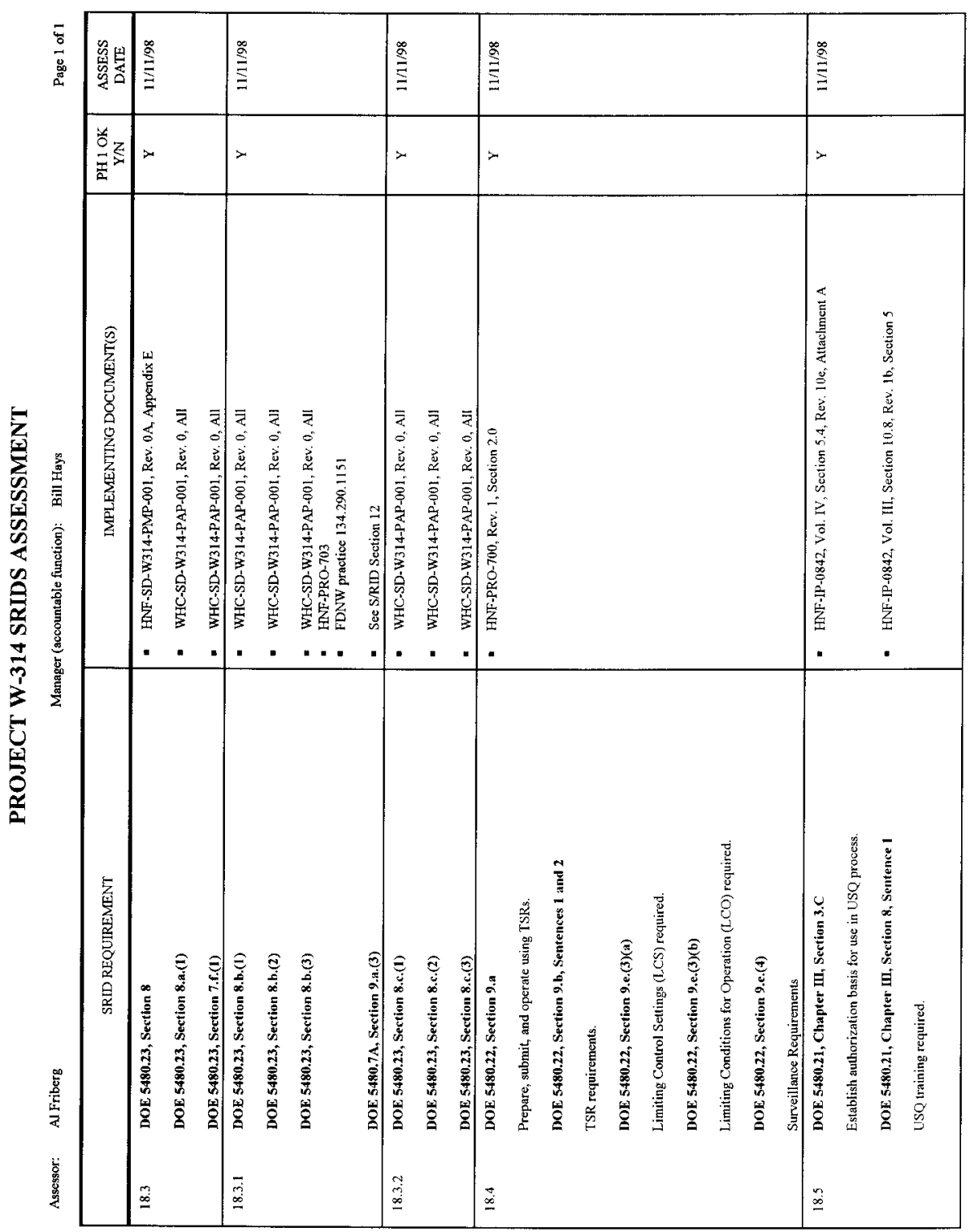


HNF-3699, Rev. 0

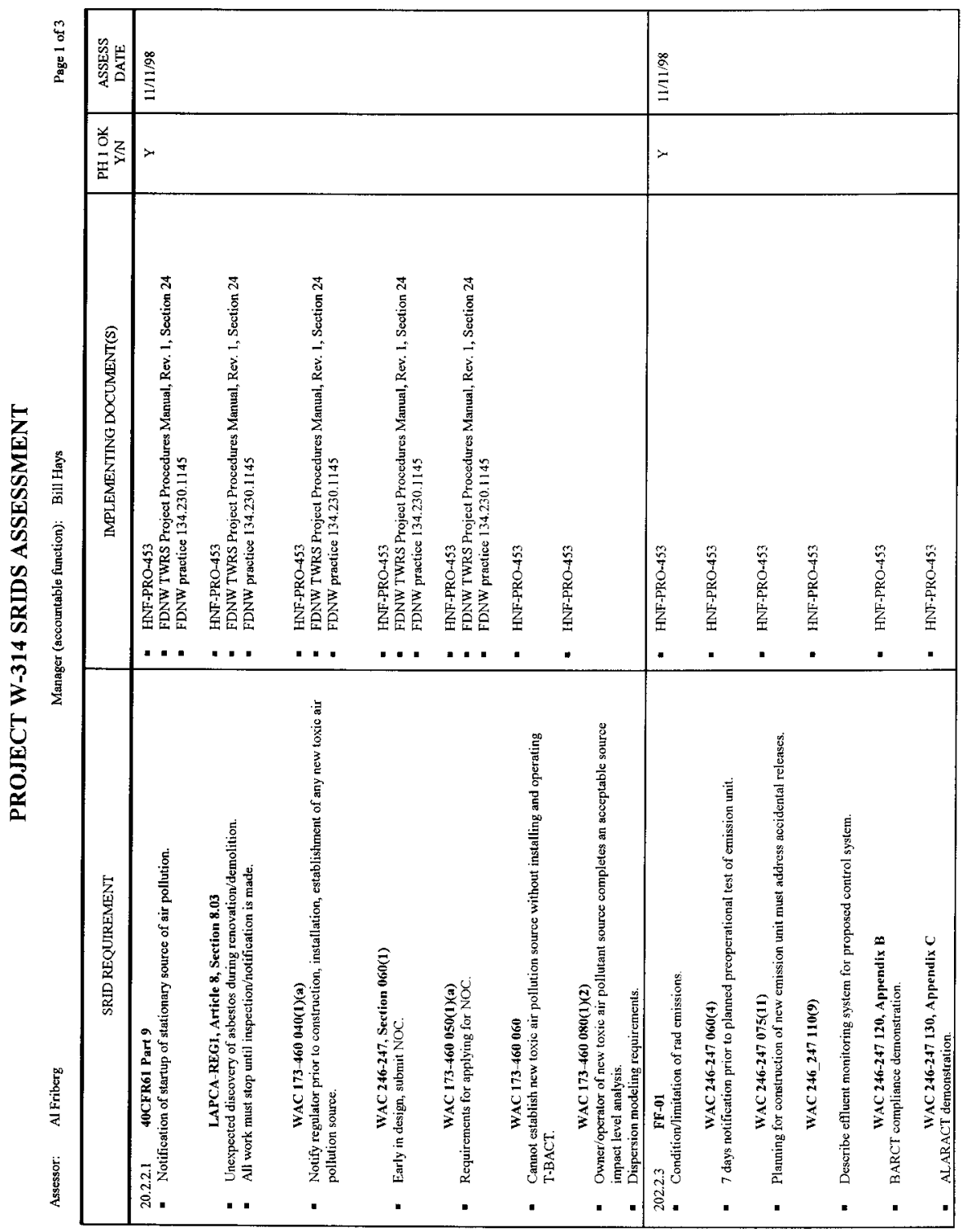


HNF-3699, Rev. 0

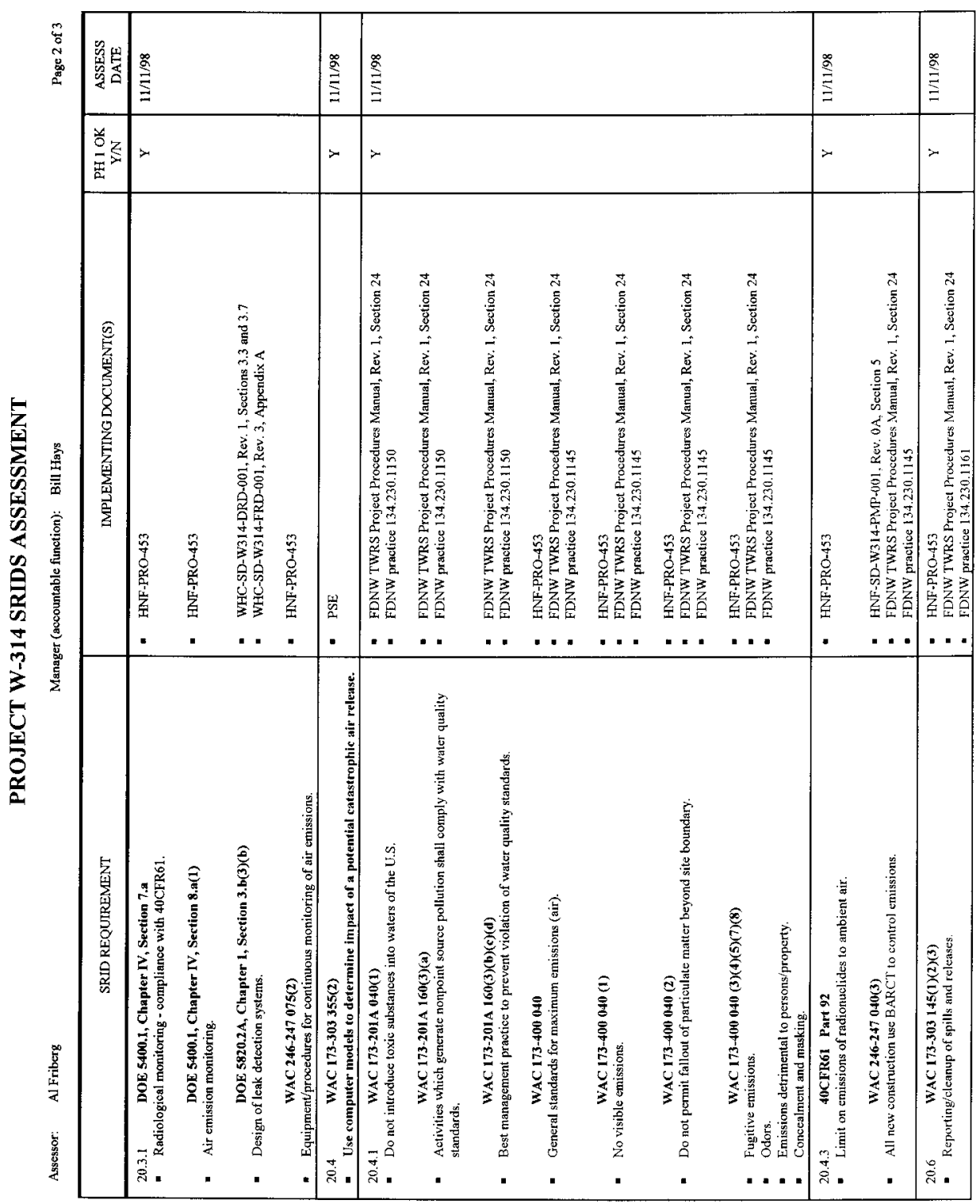


HNF-3699, Rev. 0



A - 31 
HNF-3699, Rev. 0

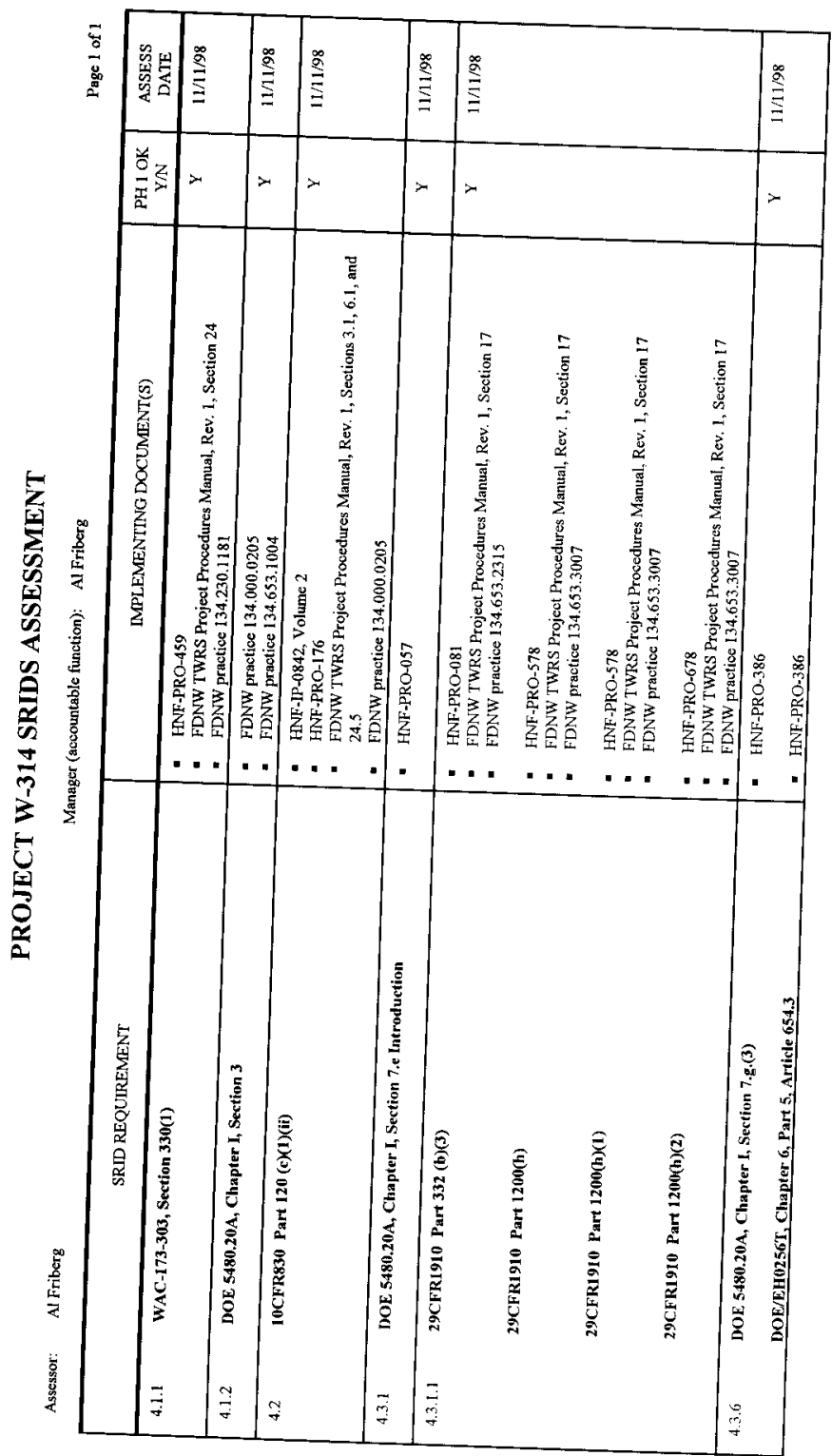


HNF-3699, Rev. 0

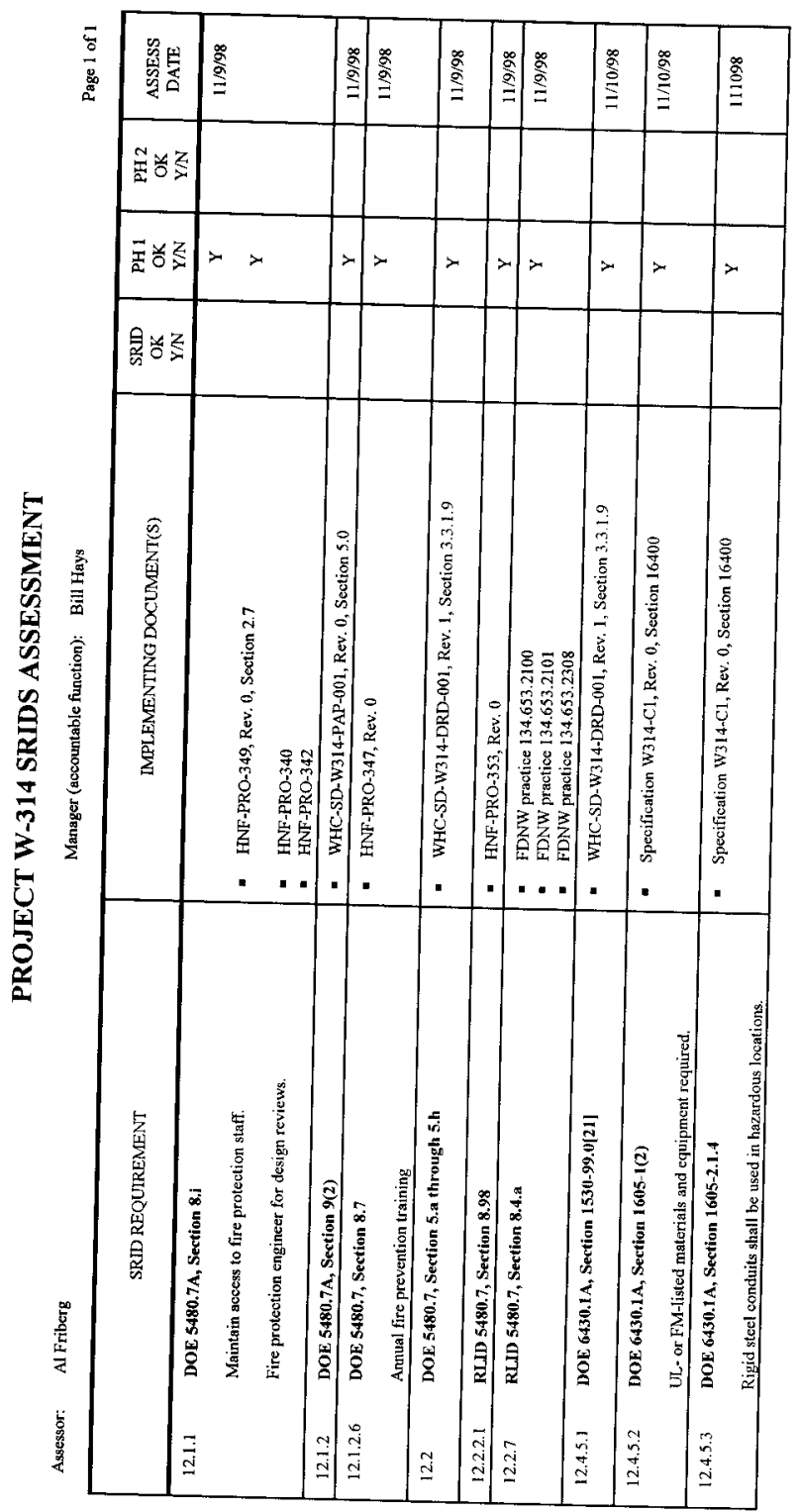


HNF-3699, Rev. 0

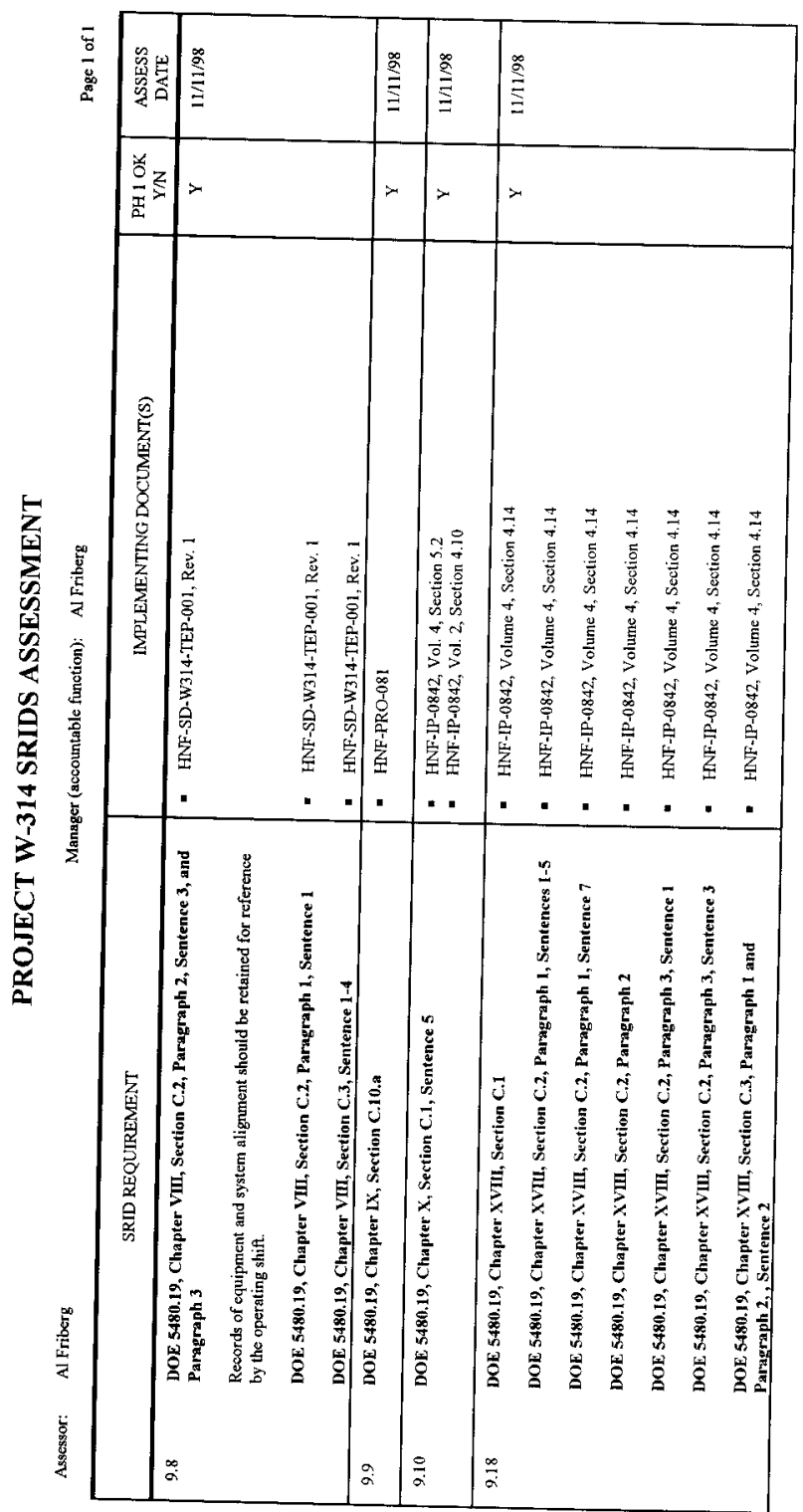


HNF-3699, Rev. 0

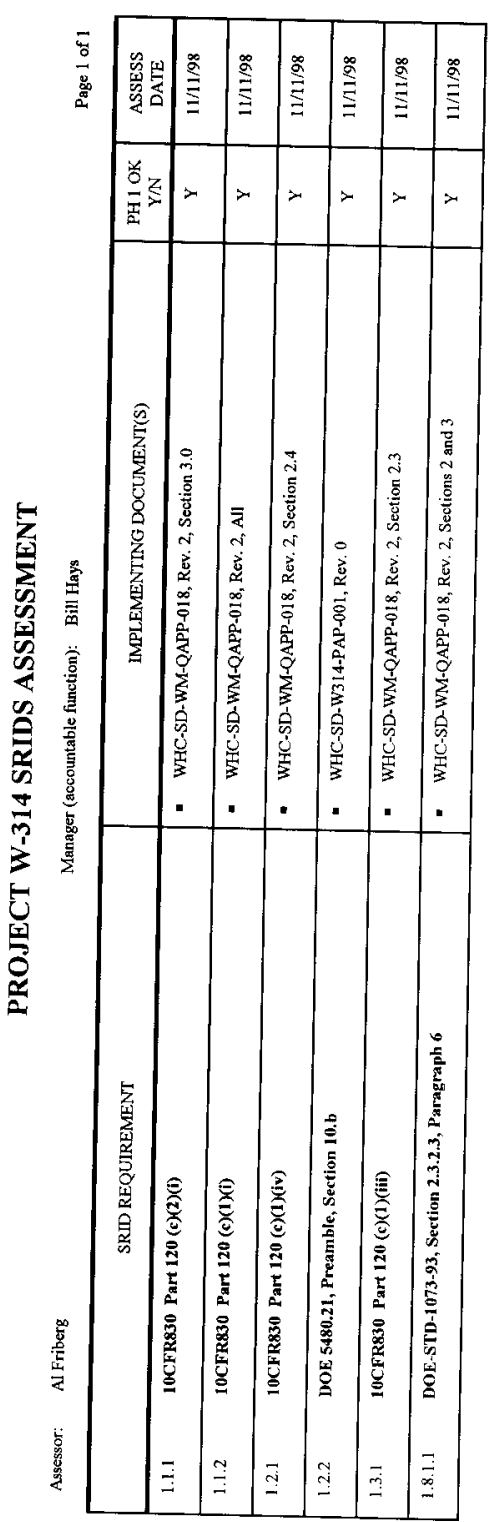


HNF-3699, Rev. 0

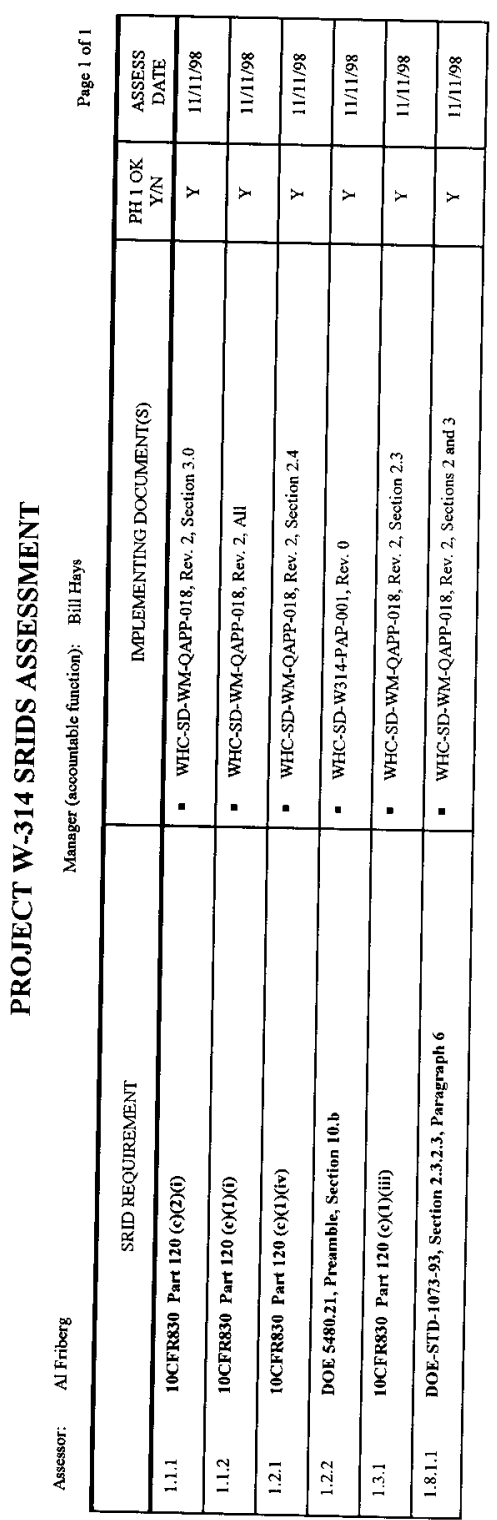


HNF-3699, Rev 0






\section{DISTRIBUTION SHEET}

\begin{tabular}{|c|c|c|c|c|c|}
\hline \multirow{2}{*}{$\begin{array}{l}\text { To } \\
\text { Ditribution }\end{array}$} & \multirow{2}{*}{\multicolumn{3}{|c|}{ From }} & \multicolumn{2}{|c|}{ Page 1 of 1} \\
\hline & & & & \multicolumn{2}{|l|}{ Date 3/1/99 } \\
\hline \multirow{2}{*}{\multicolumn{4}{|c|}{$\begin{array}{l}\text { Project Title/Work Order } \\
\text { Project W-314. Tank Farm Restoration and Safe Operations }\end{array}$}} & \multicolumn{2}{|c|}{ EDT No. 618715} \\
\hline & & & & \multicolumn{2}{|l|}{ ECN No. } \\
\hline Name & MSIN & $\begin{array}{c}\text { Text } \\
\text { With } \\
\text { Al] } \\
\text { Attach } \\
\end{array}$ & $\begin{array}{l}\text { Text } \\
\text { Only }\end{array}$ & $\begin{array}{c}\text { Attach } \\
/ \\
\text { Appendi } \\
x \\
\text { only }\end{array}$ & EDT/ECN \\
\hline
\end{tabular}

D. D. Barkost

P. J. Bedell

T. W. Bohan

D. E. Bowers

H. M. Chafin

R. A. Dodd

A. H. Friberg

J. D. Galbraith

M. S. Garret

J. L. Gilbert

W. H. Hays

J. L. Homan

J. T. Koberg

A. S. Langevin

$\mathrm{J}$. R. Lapointe

R. L. Legg

D. L. McGrew

J. W. Middleton

M. D. Rickenbach

W. T. Thompson

M. S. Tiffany

T. L. Warnick

Construction Document Control

Document Control
$\mathrm{R} 2-82$
G3-12
R3-47
S $5-13$
R3-25
R3 -72
E6-05
R3-73
S5-50
R3-25
B 4 -57
R3-25
G3-12
E6-46
R2 -88
R4-06
R3 -25
B $4-68$
G3-12
R3-73
R1-49
G3-12
S2-53
R $1-29$

For changes in Distribution, please contact Tammy Rettkowski at 372-2559 or Linda Syverson on 376-0486. 